\title{
The Potential Influence of the Bacterial Microbiome on the Development and Progression of ADHD
}

\author{
Stephanie Bull-Larsen and M. Hasan Mohajeri *(1) \\ Institute of Anatomy, Department of medicine, University of Zurich, Winterthurerstrasse 190, \\ 8057 Zürich, Switzerland; stephanie.bull-larsen@uzh.ch \\ * Correspondence: mhasan.mohajeri@uzh.ch; Tel.: +41-79-938-1203
}

Received: 15 October 2019; Accepted: 13 November 2019; Published: 17 November 2019

\begin{abstract}
The latest research cumulates staggering information about the correlation between the microbiota-gut-brain axis and neurodevelopmental disorders. This review aims to shed light on the potential influence of the microbiome on the development of the most prevalent neurodevelopmental disease, attention-deficit-hyperactive disorder (ADHD). As the etiology and pathophysiology of ADHD are still unclear, finding viable biomarkers and effective treatment still represent a challenge. Therefore, we focused on factors that have been associated with a higher risk of developing ADHD, while simultaneously influencing the microbial composition. We reviewed the effect of a differing microbial makeup on neurotransmitter concentrations important in the pathophysiology of ADHD. Additionally, we deduced factors that correlate with a high prevalence of ADHD, while simultaneously affecting the gut microbiome, such as emergency c-sections, and premature birth as the former leads to a decrease of the gut microbial diversity and the latter causes neuroprotective Lactobacillus levels to be reduced. Also, we assessed nutritional influences, such as breastfeeding, ingestion of short-chain fatty acids (SCFAs) and polyunsaturated fatty acids (PUFAs) on the host's microbiome and development of ADHD. Finally, we discussed the potential significance of Bifidobacterium as a biomarker for $\mathrm{ADHD}$, the importance of preventing premature birth as prophylaxis and nutrition as a prospective therapeutic measurement against ADHD.
\end{abstract}

Keywords: microbiome; microbiota-gut-brain axis; ADHD; attention-deficit-hyperactive-disorder

\section{Introduction}

The microbiota-gut-brain axis is a bidirectional communication pathway between the microbiota, gut and central nervous system (CNS). It has been estimated that over $10^{14}$ microorganisms, which include bacteria, archaea, and eukaryota, reside in the gastrointestinal tract (GI-tract) [1]. According to the latest study, this results in an approximately equal number of microbial compared to human cells in an individual [2]. The microorganisms residing in the GI-tract play an important role in protecting humans from potential GI pathogens [3], and also exert neuroactive properties which explains why this ecosystem does not only influence the gut, but also the brain. Research shows the great importance of a healthy microbial composition in the gut at an early stage in life (2-3 years of age), a period also characterized by intense neurodevelopment in humans. Several reports conclude that early gut dysbiosis can influence the neurodevelopment in the short run and may also lead to mental health issues later in life [4,5].

Research highlights this risk, as gut dysbiosis in child or adulthood has not only been associated with various diseases, such as irritable bowel syndrome [6] or obesity [7], but also with psychiatric disorders as, for example, depression [8], Parkinson's disease (PD) [9], schizophrenia [10], autism spectrum disorder (AS) [11], and lastly, attention-deficite-hyperactive-disorder (ADHD) [12]. 
ADHD is an early onset neurodevelopmental disease that, according to the fifth edition of Diagnostic and Statistical Manual (DSM-V), can be characterized into different representations: Hyperactivity and/or impulsivity, inattentiveness or all combined [13]. The worldwide prevalence of ADHD in children under the age of 18 ranges from 5.3\% [14] to 7.2\% [15], making it the most frequent neurobehavioral diagnosis in children. Interestingly, varying prevalence levels are reported in different geographies, which are primarily due to different characteristics of methods employed for ADHD diagnosis rather than geographic variations [14]. Nonetheless, $30-60 \%$ of the children continue to show symptoms into adulthood and thus, $1-6 \%$ of the population develop adult ADHD [16]. This is predominantly represented by the inattentive type [17].

This literature review attempts to identify and discuss factors that may influence the microbiome, and thus, could be associated with the development or progression of ADHD. Thereby we concentrate solely on the influence of bacteria rather than archaea and eukaryota. Furthermore, we evaluate the biochemical changes in ADHD patients and to what extent these can be related to microbial alterations in the gut. Finally, we reconfirm known biomarkers and deduce possible new ones for the diagnosis of ADHD and conclude what factors worsen or alleviate the development and progression of ADHD as this might lead to potential intervention methods of the neurodevelopmental disorder.

\section{Materials and Methods}

The key research question of this literature review is: What factors may influence the microbiome and could be associated with the development and/or progression of ADHD? The databases Pubmed and Scopus were searched until the 1 July 2019 with the following MeSH and search terms: "Microbiome", "microbiota", "gut-brain axis", "microbiota-gut-brain-axis", "ADHD". Most of the research papers included in this review were published between 2010 and 2019.

As our primary focus was on bacteria, we excluded studies that concentrated on archaea and eukaryota. The incorporated studies had to fulfill all of the following inclusion criteria:

- Articles were directly related to the topic;

- ADHD patients were diagnosed by a medical expert;

- Publication in a peer-reviewed journal;

- Availability of the full-text publication;

- Studies were written in English.

A total of 208 citations were included in this article.

\section{Evidence Linking Microbiota to ADHD}

\subsection{Microbiome}

The influence of the microbiome on the ADHD pathophysiology is being intensively researched. The microbiota consists of the different microorganisms [18], and the microbiome describes the entire genome of the microbiota [18]. The primary functions of the microbiota include: (i) Protecting the host organism against pathogens by increasing the mucine production, and thus, stabilizing the gut-blood barrier; (ii) support of the immune system [19]; (iii) the production of vitamins [20]; and (iv) short-chain fatty acids (SCFAs), whereby the latter are products of microbial catabolism of indigestible carbohydrates [21]. Throughout the GI-tract, the composition and density of microbes changes, increasing from $10^{2}$ cells per gram of content in the stomach to $10^{8}$ cells per gram in the cecum [22]. Additionally, up to 1000 different bacterial species have been found to inhabit the GI-tract of humans [23]. Thereby the composition in species of the microbiome can be influenced by genetics [24], geography [25], disease, medication [26], and age [27].

The GI-microbiota goes through a physiological change from its prenatal period until the age of three [27]. For a long time, it has been thought that the intrauterine environment is sterile and that the first bacterial colonization of the newborn happens during delivery [28]. However, numerous 
studies have shown that bacteria exist in the placenta, amniotic fluid [29-31], and meconium [32] indicating that the unique microbial composition in utero may already influence the development of the microbiome of the fetus before birth. Research demonstrates that the microbiome of the placenta is low in richness and diversity and is predominantly colonized by the phyla Proteobacteria and Bacteroidetes. The former is mostly represented by the spp. Escherichia coli and Neisseria lactamica, while Bacteroidetes is dominated by Bacteroides spp. [31]. Other important phyla include Firmicutes, Fusobacteria and Tenericutes [31], whereby the latter includes genera, such as Mycoplasma and Ureaplasma [33].

The colonization of the gut in the postnatal period is sensitive to environmental factors. Nonetheless, the normal composition of the microbiome in a newborn is low in diversity and shows dominance in Proteobacteria and Actinobacteria [34]. More specifically, Proteobacteria shows its peak at birth, whereas Actinobacteria increases and dominates at the age of four months [35]. At this point, Proteobacteria is still mostly represented by Escherichia coli and Actinobacteria by the genus Bifidobacterium longum [35]. As seen in Figure 1, at the age of three and onwards, the microbiome stabilizes to four major phyla: Firmicutes, Bacteroidetes, Actinobacteria, and Proteobacteria, which normally cover more than $90 \%$ of the total bacterial population in a human body [36].



Figure 1. The most prevalent bacterial phyla in utero and in the GI-tract of humans. This figure represents the dynamic and development of the composition of the microbiome from fetuses in utero until the age of three years, at which point the microbiome gains its stability and consists of mostly four phyla: Proteobacteria, Actinobacteria, Firmicutes, and Bacteroides.

\subsection{Gut-Brain Axis}

The gut-brain axis describes the bidirectional communication between the microbes, enteric nervous system and the CNS [37]. So far, there are three known means of communication between these compartments: Neural, immune, and endocrine [4,38].

The neural pathway describes the hypothalamic-pituitary-adrenal axis (HPA axis), which is the most important efferent stress pathway. It is of great importance to understand to what extent the HPA axis plays a role in the pathogenesis of ADHD, as it influences pathways in the body that are often deviating in ADHD patients [39,40] as for example: Circadian rhythm [41], sleep [42], and emotions [43]. The stimulation of the HPA axis by stress or pro-inflammatory cytokines results in a release of corticotropin-releasing factor (CRF) from the hypothalamus, as well as adrenocorticotropic hormone (ACTH) from the pituitary gland, finally resulting in the secretion of cortisol from the suprarenal (adrenal) glands [38].

One study using 69 healthy children and 123 children with ADHD observed an increase in salivatory cortisol in ADHD patients after waking up in the morning [44]. The effect of stressors was studied in one paper showing that after being exposed to stress children with ADHD of combined type (high levels of hyperactivity and impulsivity) have decreased salivary cortisol levels in comparison to other ADHD patients [45]. In contrast, adult ADHD patients with an inattentive type showed higher levels of cortisol in comparison to the combined types, which showed normal levels of cortisol [46]. Finally, Lackschewitz et al. discovered that adults with ADHD who undergo a stress-inducing exam show a trend towards reduced cortisol levels [47]. These reports portray the association between altered cortisol levels and different types of ADHD. However, the heterogeneity of the results can be explained by various stressors on a differing target group all acting as confounders. Thus, only future 
studies using the same stressor, examining similar and large patient groups will allow drawing further reliable conclusions.

The neuroimmune communication pathway describes how intestinal microbes influence the function and maturation of immune cells in the CNS, whereby microglia cells play an important role [48]. These cells are activated, as well as produced, by pro-inflammatory cytokines, and are important regulators for autoimmunity, neuroinflammation, and neurogenesis [49]. Germ-free (GF) mice showed defects in microglia activation, which in turn lead to a deficient innate immune response when exposed to pathogenic bacteria [50]. The same study showed the immense effect the microbiome has on microglial cells, as introducing microbiota into GF mice resulted in restored microglial functions. Reversely, eradicating various bacteria in specific pathogen-free (SPF) mice resulted in microglial cells maturing less rapidly [50]. As neuroinflammation plays an important part in the pathophysiology of ADHD, the proper activation and maturation of microglia in ADHD patients have to be thoroughly investigated in order to determine if it has a pathogenic influence.

The enteric nervous system communicates with the brain mainly through the parasympathetic vagus nerve [51], and partially though the sympathetic spinal cord pathway [52]. Furthermore, the vagus nerve predominantly consists of afferent nerve fibers with a ratio of 9:1 to efferent fibers [53]. Even though a definite conclusion cannot be made, various studies have demonstrated that the autonomic nervous system of ADHD patients shows alterations. A study testing 19 children with ADHD showed that the patients had an underactive parasympathetic and an overactive sympathetic nervous system [54]. Another study comparing 32 ADHD patients to 34 healthy controls registered under-aroused parasympathetic nervous systems, while the sympathetic part did not show any difference between the groups [55].

It has become clear that all three ways of communication between the microbiome, gut, and CNS could play an important role in the pathophysiology of ADHD. The neural communication over the HPA axis shows abnormalities in ADHD patients. Additionally, studies detected that microbes influence the function of pro-inflammatory microglia, a key finding, as neuroinflammation in ADHD patients is commonly found. Finally, the autonomic nervous system shows aberrations as the main research results show an under-arousal of the parasympathetic nervous system.

\subsection{Etiology of ADHD and the Genetic and Environmental Influences}

As the exact pathophysiology of ADHD is still unclear, its causes are still being researched. Nevertheless, it has been established that there is an interplay between genes and the environment resulting in a complex etiology. Genetic predisposition plays an important part in the pathophysiology of ADHD as children from parents that have been diagnosed with ADHD have a $50 \%$ higher chance to be diagnosed with the same disorder [56]. Similarly, twin studies have shown a high heritability, as especially for inattentive and combined types an inheritance of $71-90 \%$ could be discovered $[56,57]$. On the other hand, one study showed, that $20-30 \%$ of the risk of developing ADHD is due to environmental factors [58]. These include perinatal maternal smoking, stress, mineral and micronutrient deficiencies and premature birth [59]. Additionally, research showed that $10-40 \%$ of the variance inheritance of ADHD could be caused due to the environment highlighting the interplay of genetic and environmental risk factors [60]. Due to these complex interactions, it is believed that ADHD can be manifested with highly heterogenous symptoms depending on the exact pathway and etiology involved [61].

Research shows that the dysfunction of monoaminergic neurotransmitters, including noradrenaline (NE), serotonin (5-HT) and dopamine (DA), plays an important role in the pathophysiology of ADHD [62].

\subsubsection{Dopamine}

DA is a catecholamine that acts both as a hormone and neurotransmitter (NT). It is a product of the essential amino acid L-phenylalanine, which must be provided in our diet. As seen in Figure 2, this is then turned into L-tyrosine, and finally into DA and NE [63]. 


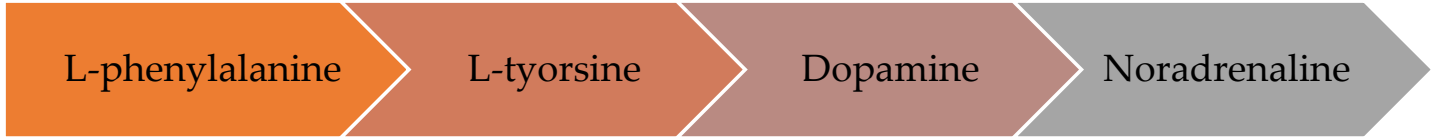

Figure 2. The synthesis pathway from L-phenylalanine to noradrenaline including all its intermediary products. Dopamine acts as an important metabolite for the emotional response and reward system [64].

The dopamine hypothesis links ADHD to alterations in dopamine metabolism. The hypothesis describes the increased expression of presynaptic dopamine transports (DAT) in ADHD patients leading to an increased dopamine transporter density (DTD), and finally results in a decreased level of the bioavailable NT [65]. The dopamine hypothesis gained attention due to the way methylphenidate (MPH) and amphetamines (AMP), the most commonly used pharmacotherapies to treat ADHD, interact with the DA and NE metabolism. MPH and AMP exert a stimulatory effect in ADHD as they inhibit the reuptake of NE and DA by blocking the metabolizing enzyme, monoamine oxidase (MAO), thereby increasing the concentration of the two monoamines in the synaptic cleft. One differentiates between MAO-A and MAO-B as the former is mostly expressed in the liver and GI-tract and the latter in blood platelets [66]. Nevertheless, both are manifested in the CNS and are able to break down DA [66]. Furthermore, amphetamines have the ability to release NTs from the presynaptic neuron, which additionally increases the monoaminergic concentration in the synapse [67].

Moreover, recent research shows that not only the metabolization, but also the production of DA plays an important role in the pathophysiology of ADHD. One of the influencers on the production of NTs seems to be the microbiome in the GI-tract [68]. Bacteria, such as the genus Bifidobacterium belonging to the phylum Actinobacteria potentially influence the levels of available DA in the body by encoding cyclohexadienyl dehydratase (CDT) [69]. This enzyme is important for the synthesis of the essential amino acid phenylalanine [69], which acts as a precursor of the amino acid tyrosine, which in turn is metabolized into DA and lastly to NE [70]. Aarts et al. found an increase in Bifidobacterium in ADHD patients, and thus, higher levels of CDT. By analyzing BOLD responses of the ventral striatal using fMRI measurements they deduced a negative correlation between the abundance of CDT and reward anticipation [69], a key symptom in ADHD [71], and target of DA [72]. Finally, this study concluded that high levels of phenylalanine might be a risk factor for abnormal dopamine signaling and could lead to a reduced reward response [69]. Although another study supports the findings by Aarts et al. [73], the correlation still appears to be inconsistent as two older studies found a decreased level of phenylalanine in ADHD patients [74,75], even if data of source [74] are not statistically significant. Finally, a more recent study found no correlation between phenylalanine levels and ADHD [76]. A summary of these finfings is given in Table 1.

Table 1. Various studies that tested phenylalanine levels in ADHD patients. $\uparrow$ represent the increase of phenylalanine found in ADHD patients and $\downarrow$ the decrease of the amino acid in comparison to healthy controls (HC). The symbol - describes that the study found no correlation between ADHD and phenylalanine levels. The accumulative data to date do not allow a definite correlation between a change in phenylalanine levels and ADHD. $p$ levels less than 0.05 were considered statistically different.

\begin{tabular}{cccc}
\hline Source & $\begin{array}{c}\text { Levels of Phenylalanine } \\
\text { in ADHD Patients }\end{array}$ & $\begin{array}{c}\text { Sample Size } \\
(\mathbf{n})\end{array}$ & $\begin{array}{c}\text { Statistical Significance } \\
(\boldsymbol{p})\end{array}$ \\
\hline$[69]$ & $\uparrow$ & 96 & $p<0.001$ \\
{$[73]$} & $\uparrow$ & 79 & $p<0.001$ \\
{$[74]$} & $\downarrow$ & 44 & $p<0.1$ \\
{$[75]$} & $\downarrow$ & 48 & $p<0.05$ \\
{$[76]$} & - & 155 & $p<0.01$ \\
\hline
\end{tabular}




\subsubsection{Tryptophan and Serotonin}

Upon intestinal absorption into the bloodstream, the essential amino acid tryptophan can cross the blood-brain barrier (BBB). Thereby tryptophan can act as the precursor of the neurotransmitter 5-HT, which plays an important part in the microbiome-gut-brain axis [77]. Although it is still unclear to what extent the microbiome influences the synthesis of 5-HT, it has been established that certain strains of bacteria, such as Streptococcus spp., Enterococcus spp., and Escheria spp. are capable of producing this NT [78]. Most of the 5-HT is produced and stored in gastrointestinal cells and affects peristalsis, nausea, satiety and abdominal pain [79]. Meanwhile, in the brain, it influences other NTs, such as DA, Cholin $(\mathrm{CH})$ and GABA, which influence memory and mood [80].

Banerjee et al. showed that 5-HT may have an influence on hyperactive and impulsive symptoms in ADHD [81]. Another study implied lower levels of 5-HT in the CNS of ADHD patients due to a decreased transport capacity of its precursor, tryptophan, into the brain [82]. Finally, one study showed that inflammation in the intestine affects 5-HT signaling pathways due to a decreased function and expression of the serotonin selective reuptake transporter (SERT) resulting in an increased level of 5-HT in the body [79]. However, it is important to remember that serotonin is not able to cross the BBB, and thus, the 5-HT pools in the CNS and the periphery do not directly interact with each other.

To demonstrate the importance of microbes on the 5-HT system, one study concluded that GF male mice have a 1.3 fold increased level of 5-HT in their hippocampus. This is an important finding as certain therapeutic medications of ADHD, such as escitalopram and lithium increase serotonin levels in a similar amount [83]. Thus, the composition and the modulation of the gut microbiota might become an interesting, future therapeutic intervention strategy.

Although the studies do not allow us to make a precise conclusion in what way bacterial-produced 5-HT influences ADHD, they do make it clear that it is one of the several catecholamines that play an important role in the pathophysiology of ADHD.

\subsubsection{Kynurenine Pathway}

Although tryptophan is the key amino acid for the production of 5-HT, $90 \%$ of tryptophan is catabolized by the kynurenine pathway [84]. This process produces nicotinamide adenine dinucleotide (NAD) through the stimulation of inflammatory and glucocorticoid metabolites. The kynurenine pathway has received attention in regards to psychiatric diseases, such as depression and schizophrenia $[80,85,86]$ as it uses most of the tryptophan, and thus, leaves a limiting amount of substrate for the synthesis of serotonin.

Intermediate products, such as kynurenine, kynurenic acid (KA), xanthurenic acid (XA) and quilonoic acid (QA) can influence the immune system and neurotransmission [87]. The three former metabolites have anti-inflammatory properties as KA inhibits the NMDA-gated ion channels [88], and XA interferes with the glutamatergic neurotransmission [89]. Also, these products decrease the amount of pro-inflammatory IFN gamma in comparison to the anti-inflammatory IL-10 [87]. In contrast, QA stimulates microglial cells and increases the ratio of IFN gamma/IL-10 [87], resulting in pro-inflammatory effects [90]. Although KA shows neuroprotective properties, human and animal studies show that high levels of KA are associated with cognitive abnormalities, such as attention and memory issues typically associated with psychiatric disease [91,92].

Studies regarding levels of tryptophan and metabolites of the kynurenine pathway show inconclusive results. A Norwegian study, using 133 adult ADHD patients and 133, did not find that the ADHD group had lower levels of tryptophan and neuroprotective KA and XA [86]. These data were confirmed by another study testing ADHD children, which exhibited lower KA and XA levels [93]. These researchers, however, recorded higher levels of tryptophan in ADHD subjects [93]. These data do suggest an association between low levels of KA and XA in ADHD, but as there are still too few studies on this topic, it is difficult to deduce a definitive connection between tryptophan, its metabolites, and ADHD. 
The various steps of the kynurenine pathway are dependent on coenzymes, such as the activated form of vitamin B6, pyridoxal 5' -phosphate (PLP). One study found an inverse correlation between serum levels of vitamin B6 and ADHD including its symptom severity [94]. Similarly, Aarsland et al. also observed a decrease in vitamin B6 in their patient group. Other data suggested that vitamin B6 metabolism plays a key part in the pathophysiology of ADHD, as vitamin B6 dependent enzymes show severe abnormalities in the ADHD test group [95]. Thus, lower levels of intermediate metabolites could be related to a deficiency of enzyme substrate. This data supports the importance of optimal coverage of ADHD patients with vitamin B6. The microbiome could play a potentially important role, as bacteria in the large intestine produce this vitamin [96]. As the correlation between levels of vitamin B6 and ADHD are relatively new, future studies are warranted to asses to what extent the microbiome can influence vitamin B6 levels on a therapeutic level.

\subsubsection{Gut Dysbiosis and Immunology}

High variability in gut flora prevents the growth of pathogenic bacteria, and thus, stops gut dysbiosis [97]. The term dysbiosis describes a microbial imbalance in which there is a shift from protective to pathogenic microbes in the GI-tract [98]. This can lead to a growing GI-permeability which leads to an increase in migration of pathogenic microbes and translocation of their metabolites into the systemic circulation potentially resulting in systemic inflammation [99]. This can, in turn, decrease the permeability of the BBB, which can lead to inflammation of brain parenchyma [100]. Severe dysbiosis has been associated with chronic inflammatory intestinal disorders and psychiatric illnesses, such as schizophrenia, anxiety, depression [98], and ADHD [90,101]. A systematic review supports the latter findings concluding that patients with ADHD have increased levels of inflammatory cytokines [102]. Similarly, Verlaet et al. also detected increased levels of pro-inflammatory cytokines (IFN gamma and IL-6) in the serum of ADHD patients [101].

An imbalance of pro-inflammatory cytokines can also lead to allergic disease [103], and a positive correlation between ADHD and allergies has been shown in different cohorts [104-106]. Additionally, research has shown an association between an altered gut microbial composition and the tendency to suffer from the allergic disease [107].

An important pro-inflammatory cytokine is interleukin (IL-6). This has been inversely associated with the bacterium Dialister spp. [108]. Dialister spp. is shown to correlate with an altered temperament and impulsiveness in toddlers positively. These commonly found ADHD symptoms were measured using the Early Childhood Behavior Questionnaire (ECBQ), which measures extroversion, activity levels and feelings of high-intensity pleasure [109]. Furthermore, a review evaluating multiple studies concluded an increase in pro-inflammatory metabolites, such as IL-6 and IL- 1 in patients with ADHD [110]. Nonetheless, one study showed that ADHD patients had significantly lower levels of Dialister spp. in comparison to healthy controls (HC), hinting towards decreased feelings of activity and lower levels of intense pleasure, and finally higher levels of IL-6 [111].

Although the association between Dialister spp. and feelings of pleasure are new findings; and it is important to note that pro-inflammatory interleukin levels are increased in ADHD patients. As high levels of pro-inflammatory interleukins can be linked to neurological inflammation that can lead to a decrease of cortical volume and altered behavior [110,112], reducing the activity of these pro-inflammatory cytokines could represent a vital prophylaxis strategy in ADHD management.

Patients with th2-mediated atopic disorders, such as eczema, asthma and allergic rhinitis have a 30-50\% higher chance of developing ADHD [113]. Eczema is an inflammatory skin disease and is the most prevalent chronic condition in early childhood [114]. Children suffering from atopic dermatitis (eczema) have a 50\% likelihood of developing asthma and allergic rhinitis, exhibiting airway inflammation and clear nasal discharge, respectively [115]. Th2-cytokines are important for eosinophilic recruitment and the production of IgE by B-lymphocytes. All of these processes are associated with allergies and inflammation of the skin (e.g., eczema) $[116,117]$ as they activate the production of pro-inflammatory cytokines, such as IL-6, IL-1beta, TNF-alpha and IL-8 [103]. Studies have shown that 
these atopic diseases are associated with a low level of Faecalbacteria spp. In the gut [118]. This species is known to have anti-inflammatory effects on the organisms $[119,120]$. As explained above, patients with ADHD seem to exhibit higher levels of inflammatory markers which could potentially support the hypothesis that low levels of Feacalbacteria spp. Cause an increase of inflammation which affects the development of the brain, and finally the pathogenesis of ADHD.

\section{Results}

\subsection{Obstetric Mode of Delivery: Vaginal Birth vs. Caesarean Section (C-Section)}

As infants delivered by vaginal birth move through the birth canal, they get colonized by their mother's vaginal microbiota, and thus, adopted a resembling gut microbiome. In contrast, infants born via c-section are colonized by the microbiota of their mother's skin. Therefore, the delivery mode affects the composition of the gut microbiota in infants [121].

Results of various studies showed that in comparison to vaginally born infants, babies delivered by c-section had a decreased gut microbiota diversity including lower levels of Bifidobacterium spp. and Bacteroidetes, but increased levels Clostridium difficile [122] up until the age of two years [123].

Several research groups studied the correlation between c-section delivery and ADHD (see Table 2). An animal study showed a correlation between offspring born via c-section and altered dopamine metabolism throughout development [124]. It is important to note that these results might have been confounded by indication, which means that the altered dopamine response might be due to triggers that lead to a c-section [125]. In contrast to the above findings, two previous case-control studies found no significant correlation between c-sections and ADHD [126,127] in humans. A systematic review by Curran et al. initially showed a slight increase in the prevalence of ADHD in children born via c-section [128]. This correlation was challenged in their later study due to confounders, such as not differentiating between elective and emergency c-sections [129]. The only correlation that still seemed to be consistent was an increased prevalence of ADHD in children born via emergency c-sections. Confirmative data were obtained in a prospective cohort study using 671,592 Danish children. They found a significantly increased chance of children developing ADHD (Hazard Ratio 1.21) for intrapartum c-sections, but no effect when born by an elective c-section [130]. In contrast, the Millenium UK cohort study testing 13,141 children found no correlation between ADHD and mode of delivery despite differentiating between emergency, planned and induced c-sections [131].

Table 2. List of seven studies that tested the effects of c-section delivery on the development of ADHD. The table describes if the studies differentiated between the types of c-sections and their effects, and finally shows the sample size and statistical significance level of the individual studies. The symbol represents that for these studies, this information could not be found as the studies were systematic reviews. The data shows that elective vs. emergency c-sections seem to have different effects on ADHD. $p$ levels less than 0.05 were considered statistically different.

\begin{tabular}{|c|c|c|c|c|}
\hline Source & Type of C-Section & Effect & $\begin{array}{l}\text { Sample Size } \\
\text { (n) }\end{array}$ & $\begin{array}{c}\text { Statistical Significance } \\
(p)\end{array}$ \\
\hline$[124]$ & No differentiation & Altered dopamine response & - & - \\
\hline [126] & No differentiation & No effect & 248 & $p=0.005$ \\
\hline [127] & No differentiation & No effect & 12,991 & $p<0.05$ \\
\hline [128] & No differentiation & Positive correlation to ADHD & - & - \\
\hline [129] & $\begin{array}{l}\text { Elective vs. } \\
\text { intrapartum }\end{array}$ & $\begin{array}{l}\text { Only intrapartum c-sections showed } \\
\text { a positive correlation to ADHD }\end{array}$ & $1,722,548$ & $p<0.05$ \\
\hline$[130]$ & $\begin{array}{l}\text { Elective vs. } \\
\text { intrapartum }\end{array}$ & $\begin{array}{l}\text { Only intrapartum c-sections showed } \\
\text { a positive correlation to ADHD }\end{array}$ & 671,592 & $p<0.05$ \\
\hline [131] & $\begin{array}{l}\text { Elective vs. } \\
\text { intrapartum }\end{array}$ & No effect & 13,141 & $p<0.05$ \\
\hline
\end{tabular}

The reasons for finding a positive correlation between intrapartum c-sections and ADHD development cannot unequivocally be explained as multiple confounders, such as unobserved familial 
factors, birth weight or gestational age also directly influence the mode of delivery and ADHD. However, there is a strong indication that the microbiota plays a subordinate role in this correlation as Axelsson et al. discovered that exposure of the newborn to ruptured vs. non-ruptured membranes prior to c-section did not influence the correlation between c-section and ADHD development [130].

To conclude, the accumulative data show that the mode of delivery affects the composition of the gut microbiota. However, a clear correlation between c-section delivery and a higher chance of developing ADHD cannot be found as results depend on various confounders and the type of c-section, whereby intrapartum c-sections show a positive correlation with the development of ADHD in comparison to elective c-sections.

\subsection{Stress of the Mother}

A prospective follow up study, and a Dutch population-based cohort study concluded a correlation between prenatal maternal stress exposure and an increase in ADHD in their offspring [132,133]. This data was confirmed by a Canadian study enrolling 203 pregnant women exposed to stress. Sixty-two of them were exposed to severe prenatal stress (experienced physical or sexual abuse, or death of a close relative) and delivered children with more severe ADHD symptoms in comparison to the 48 mothers who experienced moderate stress (financial or marital troubles) [134].

An animal study using quantitative PCR determined that maternal stress significantly decreased one of the most abundant taxa in the maternal vaginal flora, Lactobacillus spp. [135]. Consequently, Lactobacillus spp. was also significantly decreased in the distal colon of the offspring of stress exposed mothers. Additionally, a review focusing on the immunomodulatory effects of Lactobacillus spp. shows that stress reduces the abundance of this species independent of the host being pregnant or not [136]. Lactobacillus spp. is important for the synthesis of acetylcholine, while together with Bifidobacteria spp. it is contributing to the production of the main inhibitory neurotransmitter GABA [137]. Alterations in the GABAergic system have been associated with neurodevelopmental diseases, such as autism spectrum disorder and ADHD. This system is especially susceptible to alterations during development as GABAergic neurons originate from a different part of the neural tube than GABA's most important counterpart, the glutamatergic system. ADHD symptoms may be explained by the hypothesis that inhibitory functions of the cerebral cortex are reduced, leading to a reduction of filtering sensory influences, and finally having difficulties choosing the right behavioral reaction [138].

As described above, several studies have associated low levels of cerebral GABA concentrations with symptoms of ADHD [139-141]. Furthermore, a randomized controlled study showed that Lactobacillus rhamnosus also has a preventive effect as the administration of this bacterium in the first six months of life reduced the risk of ADHD and Asperger Syndrome (AS) [142]. The positive effects of this species may be due to the fact that Lactobacillus rhamnosus is, on the one hand, implicated in the development of tight junctions responsible for a strong gut barrier, and on the other hand, important for the immunoglobulin A and mucin production [143].

Various factors influence the development of ADHD, among which the neuroinhibitory neurotransmitter GABA seems to play a crucial role. However, to what extent low levels of Lactobacillus spp. and decreased concentrations of GABA are associated and how they precisely affect the development of ADHD remains unclear and has to be thoroughly investigated.

\subsection{Preterm}

Preterm babies that, thus, have gone through stressful situations similarly show lower levels of Lactobacillus spp. [144], and simultaneously have a significant increase in the prevalence of ADHD $[58,145,146]$. More specifically, Barrett et al. showed an increased abundance of Proteobacteria spp., while discovering undetectable levels of Lactobacillus spp. and Bifidobacteria spp. [144,147]. Chou et al. discovered that certain strains of Lactobacillus spp. show a protective trait towards the CNS. Preterm babies received strains of Lactobacillus reuteri and Lactobacillus rhamnous as probiotics for six weeks. This treatment resulted in a significantly reduced number of babies with neurological aberrations 
at one year of age in comparison to the group fed with Lactobacillus acidophilus and Bifidobacterium infantis [148].

It is widely known that preterm infants own an immature immune system as the innate and adaptive immune system has not developed fully. Due to their immature immune response and their usual extended hospital stay, infants are highly susceptible to nosocomial spread infections [149]. The increased number of infections may impair the neurodevelopment, and thus, might influence the development of the most common neurodevelopmental disorder ADHD. In addition to this, the weeks before term delivery (between $370 / 7$ and 41 6/7) [150] represent an important stage in the neurodevelopment of the brain usually occurring in the protective womb of the mother $[151,152]$. Thus, preterm babies suffer from underdeveloped brain structures that in combination with postnatal complications, such as infections can lead to cell death of neurons, and finally lead to a decrease in the volume of specific areas of the brain [153].

As the prevalence of infection in premature newborns is high, the use of therapeutic antibiotics is similarly increased. Antibiotics have been associated with altering functions in the host's brain [154], while simultaneously, they are notoriously known for reducing the diversity of the microbiota [155]. Nevertheless, the direct effects of a lower microbiota diversity on the neurodevelopment have still not been thoroughly researched on, and thus, a concrete correlation cannot be made.

To summarize, a preterm baby is exposed to increased levels of stress, may have underdeveloped brain structures and owns an immature immune system. All of these result in a higher susceptibility to infections, and finally may lead to increased exposure to therapeutic antibiotics. These factors influence the neurodevelopment either directly through inflammatory processes during infections or indirectly by changing the composition of the gut microbiome.

\subsection{Breastfeeding vs. Formula Feeding}

Studies have associated breastfeeding with a lower prevalence of ADHD [156]. In contrast, formula-fed newborns showed a strong correlation with ADHD diagnosis [157-159]. The nutritious breast milk not only contains human milk oligosaccharides acting as prebiotics important for establishing a healthy gut microbiome, but also consists of vitamins and antibodies [160]. The latter being important in the first couple of months for the maturation of the innate immune system of the newborn [161]. Additionally, breast milk is marked to have a rich fat content due to its high levels of long-chain fatty acids, which are said to have protective effects on the CNS and the development of ADHD [162,163]. The gut microbiota of breastfed infants is less diverse in comparison to formula-fed infants [164]. Importantly, various groups utilizing differing methods for microbiome analysis, such as $16 \mathrm{~S}$ sequencing or cytogenic FISH technique discovered that in both groups, the most prevalent genus is Bifidobacterium $[122,164,165]$.

A systematic review by Guaraldi et al. showed that bottle-fed infants have a higher number of Escherichia coli, Clostridium difficile, Bacteroides spp. and Lactobacilli [166]. As seen in Table 3, research papers demonstrated that increased levels of Lactobacillus acidophilus [122], Streptococcus, Veillonella parvula [164], and Clostridium coccoides [165], were found in formula-fed infants. Although Bifidobacterium is the most prevalent genus found in both groups, breastfed infants show more than double of Bifidobacteria cells in comparison to formula-fed infants [164]. Bifidobacterium infantis has protective properties against pathogens as it supports the barrier function of the mucosa and concurrently has anti-inflammatory properties, thus, promotes a healthy immunological response $[167,168]$.

Although the effect on the microbial composition could be the main cause of developing ADHD when being formula-fed, one has to consider the fact that other ingredients in the formula may also act as important influences. One study found that there were more cases of ADHD in formula-fed infants in 2007, than in December 2011. During the latter, the neurotoxic chemical Bisphenol A (BPA) was significantly reduced in formula cans and baby bottles in comparison to the former, suggesting that BPA might be the actual trigger of the correlation [169]. 
Table 3. Listing the different genera, predominantly found in formula-fed vs. breastfed infants. The arrow $\uparrow$ describes that this genus is increased in variously fed infants, while '-' represents that there is no significant change in this genus. One can clearly see that microbial diversity is increased in formula-fed in comparison to breastfed infants. $p$ levels less than 0.05 were considered statistically different.

\begin{tabular}{|c|c|c|c|c|c|c|}
\hline Genus & Formula-Fed & $\begin{array}{c}\text { Sample Size } \\
\text { (n) }\end{array}$ & $\begin{array}{c}\text { Statistical } \\
\text { Significance } \\
(p)\end{array}$ & Breastfed & $\begin{array}{c}\text { Sample Size } \\
\text { (n) }\end{array}$ & $\begin{array}{c}\text { Statistical } \\
\text { Significance } \\
(p)\end{array}$ \\
\hline \multirow[t]{3}{*}{ Bifidobacterium } & $\uparrow[122]$ & 232 & $p<0.01$ & $\uparrow[122]$ & 700 & $p<0.01$ \\
\hline & $\uparrow[164]$ & 6 & $p<0.05$ & $\uparrow[164]$ & 6 & $p<0.05$ \\
\hline & $\uparrow[165]$ & 182 & $p<0.001$ & $\uparrow[165]$ & 312 & $p<0.001$ \\
\hline Escherichia coli & $\uparrow[122]$ & 232 & $p<0.01$ & - & 700 & $p<0.01$ \\
\hline Bacteroides & $\uparrow[122]$ & 232 & $p<0.01$ & - & 700 & $p<0.01$ \\
\hline Lactobacillus & $\uparrow[122]$ & 232 & $p<0.01$ & - & 700 & $p<0.01$ \\
\hline Veillonella parvula & $\uparrow[164]$ & 6 & $p<0.05$ & - & 6 & $p<0.05$ \\
\hline Streptococcus & $\uparrow[164]$ & 6 & $p<0.05$ & - & 6 & $p<0.05$ \\
\hline Clostridium coccoides & $\uparrow[165]$ & 182 & $p<0.014$ & - & 312 & $p<0.014$ \\
\hline
\end{tabular}

In summary, studies show that breastfeeding correlates negatively with the risk of developing ADHD, whereas formula-feeding increases this risk. Nevertheless, despite the highly nutritious content of breast milk, the gut microbiota of breastfed infants seems less diverse, but still contains the same or higher amount of protective components than formula-fed infants. Thus, alteration of the microbiome composition could potentially be a reason for the positive correlation between formula-feeding and the risk of developing ADHD.

\subsection{Short Chain Fatty Acids}

SCFAs are products of polysaccharides which could not be properly digested by the human digestive system, and thus, are broken down by microbial fermentation. Bacteria, such as Bacteroides spp. and Clostridiae spp., are two of the most important microbes for the production of SCFAs [21]. SCFAs represent not only a major energy source for microorganisms, but also show neuroactive and anti-inflammatory effects on the host $[170,171]$. A study by MacFabe et al. demonstrated that when SCFAs, such as propionic acid are intracebreoventriculary (ICV), administered to rodents, they show biochemical alterations similar to individuals who from autism [172]. Besides, the same authors found that high levels of the SCFA worsened symptoms of autistic individuals [172].

As ADHD, similar to autism, is a neurodevelopmental disease, it seems likely that SCFAs may affect the development of ADHD. Research shows that SCFAs influence the immune system, and as discussed earlier, this can influence the CNS [50]. An animal study using mice showed that the microbiome could influence the levels of the brain-derived neurotrophic factor (BDNF) via SCFA production [173]. The neurotrophin BDNF is important for neurogenesis and has a positive effect on the survival of neurons meaning that the microbiome can indirectly influence neural functions via SCFA's modulating effect on the BDNF production. The same study showed that GF mice whose BDNF levels had been decreased displayed problems with their working memory [173]. Confirmatory data were generated by Corominas-Roso et al. who showed in a human study that adults with ADHD have lower levels of BDNF compared to healthy controls [174]. Similarly, Akay et al. tested the effects of methylphenidate on BDNF levels on 50 drug-naïve ADHD boys and detected significantly increased BDNF levels in the serum and improved ADHD symptoms after eight weeks of methylphenidate treatment [175]. The same findings were found by an older study by Amiri et al. [176]. This is a direct confirmation of a potential link between the dopaminergic system, BDNF function, and ADHD. In contrast, another study enrolling 41 untreated ADHD and 107 control patients concluded that drug-naïve ADHD children had higher levels of BDNF in their plasma and that these levels are positively associated with the severity of inattentiveness [177]. 
Besides hypothesizing a compensatory mechanism in ADHD children, a potential reason for these differing results could be varying methodology as Akay et al. measured BDNF levels in the serum, known to have a higher BDNF concertation in comparison to the plasma [178].

In conclusion, SCFAs most probably affect the development of ADHD indirectly by influencing the production of BDNF.

\subsection{Polyunsaturated Fatty Acids}

Another regulator of BDNF seems to be omega-3 polyunsaturated fatty acids (PUFAs). PUFAs are long chains of carbon atoms characterized by a carboxyl group at one end and a methyl group at the other end. As they are unsaturated, they own one or more double bonds between the carbon atoms. Naturally, plant and fish oils, such as flaxseed or salmon have a high content of omega-3 PUFAs [179]. PUFAs play an important role in membrane fluidity, neuronal membranes, neurotransmission, and receptor function [180]. Furthermore, the omega-3 fatty acid, docosahexaenoic acid (DHA), is indispensable for cognition function throughout the lifespan [181]. Indeed, already intrauterine PUFA deficiencies lead to altered cognitive and attentive skills [182].

An animal study showed that omega-3 PUFAs did not only affect the levels of BDNF, but also of glial cell-derived neurotrophic factor (GDNF). The latter is especially important for the recovery of dopaminergic neurons in Parkinson's disease (PD) as it promotes the survival of the dopamine system in the nigrostriatum. Hence, GDNF is shown to be neuroprotective and supporting dopaminergic neurons in PD models, and thus, could potentially be utilized as a therapy against neurodegenerative diseases, especially PD $[183,184]$. Furthermore, another study found that lower levels of omega-3 fatty acids were associated with lower levels of BDNF in the frontal cortex of rats [185], a part of the brain where various psychiatric illnesses, such as bipolar disease can be manifested [186]. Additionally, omega-3 PUFAs show antimicrobial effects as they increase levels of Enterobacteria and Bifidobacteria, which both strengthen intestinal permeability, reducing the risk of inflammation [187]. Finally, omega-3 PUFAs have the ability to stimulate macrophages that inhibit the activation of the NLRP3 inflammasome, and thus, decrease levels of the previously mentioned pro-inflammatory IL-1beta [188]. Nevertheless, it is important to note that an excess of omega-6 PUFAs benefits the development of endotoxemia leading to low-grade systematic inflammation, explaining why a low ratio of omega-6/omega-3 PUFAs should be targeted $[189,190]$.

Human studies have discovered a negative correlation between patients with ADHD and levels of PUFAs. An Italian study examined the levels of PUFAs in the blood of 51 ADHD and 22 non-ADHD patients. PUFA levels in the blood of ADHD patients were significantly lower and correlated with behavioral symptoms, but were not associated with cognitive skills [191]. Similarly, a systematic review concluded that in all randomized control trials (RCT) analyzed (7 RCTs, $n=534)$, omega-3 PUFA supplementation led to an improvement in clinical ADHD symptoms. Furthermore, in three out of the seven RCT's $(n=396)$, the omega-3 PUFA supplementation was associated with improvements in cognitive skills [192]. Due to these findings, questions of PUFAs being a potential therapeutic medication for ADHD patients seem to be warranted.

Moreover, a double-blind trial [193] assessed the effects of inducing the noradrenaline reuptake inhibitor (Atomoxetine) conventionally used to treat ADHD, to the patient and control group and PUFAs, such as eicosapentanoic acid (EPA) and DHA solely to the ADHD patients. The medication was given on a daily basis for four months to a total of 50 children. Although PUFAs improved ADHD symptoms, this experiment showed no clinically significant difference in the ADHD Conners Parent rating scale, questioning the overall therapeutic effect of PUFAs against ADHD, even if some beneficial effects are evident [193]. Supporting these results, a systematic review discussing results of 14 meta-analyses inducing PUFAs to ADHD children showed a very small effect size when parents and teachers rated children's behavior using the Conners scale [194].

Lastly, on a microbial level, an RCT showed that the intake of PUFAs does not seem to affect the alpha or beta diversity of the microbiota of the participants. Nevertheless, it did show a 
reversible increase in genera, such as Bifidobacterium roseburia and Lactobaccilus spp., all of which are important for the production of SCFAs and maintain an anti-inflammatory environment [195]. Similarly, a commentary discussing the importance of long-chain PUFAs as a mean to restore a healthy gut microbiome, deduced that PUFA ingestion may act as a protector from developing systemic inflammation and in the long term, chronic disease. It is, therefore, hypothesized that PUFA supplementation would not only be of therapeutic importance for ADHD, but also a prophylactic measurement against cancer as inflammation leads to immunosuppression and activates immune checkpoints resulting in an optimal tumor microenvironment [196].

Although the collected data show inconclusive results concerning the effect of PUFA supplementation as a therapeutic measurement for ADHD, the indirect effects of ingesting PUFAs and its impact on the microbiome may as well be crucial determinants that could modify the metabolism and consequently the behavioral and cognitive symptoms of ADHD.

\subsection{Antibiotics}

Although the development of antibiotics has made it possible to treat life-threatening infections, the use of antibiotics reduces the microbiota diversity in the GI-tract [197]. Consequently, the use of antibiotics may elevate the number of pathogenic bacteria, such as Enterobacter, Klebsiella, Citrobacter, and Pseudomonas and decrease anaerobic bacteria [197]. For example, a human study analyzing the short term parenteral-neonatal antibiotic usage showed that it reduced the number of protective Bifidobacteria in the first couple of months of life [198]. Supporting these results, Penders et al. not only found a decrease of Bifidobacteria, but also of Bacteroides when infants administered antibiotics [122].

Results concerning the correlation of early antibiotic use and later risk of developing ADHD seem to be incoherent. A Danish population-based cohort study did not find an association in sibling-stratified Cox model between antibiotic use in the first two years of life and the risk of developing ADHD [130]. Another study, however, using 871 European newborns examined the effects of early antibiotic treatment on cognitive functions with the help of IQ and reading tests, and on symptoms of ADHD using the mentioned Conners Rating Scale-Revised (CRS-R). Thereby they discovered that children who consumed antibiotics in the first year of life showed a reduced reading ability score, higher scores on the CRS-R, rated by parents, and increased symptoms of ADHD at the ages of 7-11 years. Nonetheless, this association was not made for babies and children that used antibiotics between the ages of 12 months and 3.5 years. This indicates that one of the vital factors for developing ADHD is the age in which the newborn consumes the antibiotics. It seems that during the first 12 months of life, important developments of the gut-brain axis take place, which when disrupted influence the neurodevelopment, and thus, the CNS in the long run [12]. These data, however, must be interpreted with caution, as this was not an RCT. Accordingly, direct causation between the antibiotic use and later seen ADHD cannot be correctly made [199].

\subsection{Probiotics}

By definition of the FAO/WHO probiotics are "live microorganisms which when administered in adequate amounts confer a health benefit on the host" [200]. Benefits of probiotics include reinforcing a more desirable environment in the gut, a healthy digestive system, and finally an adequate immune system [201]. Thereby probiotics help to sustain and produce healthy enzymes while eradicating potentially harmful pathogens [202,203]. Naturally occurring probiotic sources include lactic acid fermented vegetables, such as kimchi or fermented dairy products as, for example, yogurt [204].

The influence of probiotic strains on psychiatric diseases has been examined by multiple studies, concluding a positive effect on such illnesses and are, thus, described as "psychobiotics" [90]. An animal study using mice showed that probiotic ingestion of Bifidobacterium longum and breve led to a reduction of depression and anxiety symptoms [205].

The seminal study by Pärtty et al. researched the effects of probiotic use on the development of ADHD in children by randomly administering strains of Lactobacillus rhamnosus into 75 infants. 
The infants were monitored at three weeks, 3, 6, 12, 18 and 24 months, and finally, at 13 years of age. The authors concluded that at the age of 13 years, ADHD was diagnosed in 6/35 (17.1\%) children using the placebo, whereas no children had this disorder in the probiotic group. These results, even if encouraging, do not identify any specific composition of the microbiota to the neurodevelopmental disease, and thus, might mean that probiotics decrease ADHD in a different way rather than influencing the composition of the microbiome [142]. However, it is important to conclude that these findings potentially represent a method to reduce the risk of developing ADHD.

\section{Discussion}

This literature review demonstrates that the ADHD population has a different gut microbial composition in comparison to healthy controls as the phylum Actinobacteria is more and Firmicutes less abundant in ADHD patients. The genus Bifidobacterium, belonging to the phylum Actinobacteria, seems to play a significant role in the pathogenesis of ADHD and is recurrently influenced by several factors. Bifidobacteria do not only protect the barrier function in the gut and support a healthy immune response [168], but also influence the dopamine system by elevating the production of CDT which increases phenylalanine levels, and finally, results in higher levels of dopamine. This review showed that Bifidobacterium was decreased in offspring that were born (i) via c-section delivery $([122,123]$, (ii) as preterms [144,206], (iii) were breastfed [164] or (iv) were given antibiotics in the first months of life $[122,198]$. All of these factors are simultaneously associated with an increased risk of developing ADHD. Nevertheless, using Bifidobacterium as a potential biomarker for diagnosis of ADHD seems uncertain due to varying results regarding Bifidobacterium levels in ADHD patients. Although Pärtty et al. observed decreased levels of Bifidobacterium in 3 and 6-month-old ADHD patients [142], Aarts et al. detected slightly increased levels of the genus using a larger sample size and a more sensitive methodology [69]. Thus, for future research, well-designed studies, using a larger sample size, are needed to deduce a definite correlation between levels of Bifidobacterium and ADHD and the importance of this genus as a biomarker.

Additionally, this article concludes that the concertation of neuroprotective BDNF, indirectly influenced by the microbiome [173], plays a vital role in the pathogenesis of ADHD. The majority of reports showed a negative correlation between levels of BDNF and ADHD [173,174,207]. As the levels of SCFAs [173], and PUFAs [185] are positively correlated with BDNF, omega-3 fatty acids may prove to be of therapeutic importance. So far, various studies have shown that adding PUFAs to the diet only marginally decreases the symptoms of ADHD [193,194,208]. Future studies could assess the effects of various concentrations of PUFAs and age at which these were ingested on the symptom development of ADHD. BDNF shows properties important for neurogenesis in the critical stages of neurodevelopment. The production of SCFAs by the microbiome has been positively associated with levels of BDNF [173]. Therefore, increasing SCFAs through fiber-rich nutrition in combination with the appropriate gut microbial composition could also be a beneficial means for the treatment of ADHD symptoms.

It is widely known that c-section delivery causes the offspring's microbiome to be more similar to the mother's skin rather than her vaginal flora. However, it is still under debate to what extent this change impacts the development of ADHD. We decided to concentrate on the more recent papers, that used a large sample size and a precise methodology by differentiating between elective and emergency c-sections. These studies show that not every c-section increases the risk of developing ADHD, but only those that were done intrapartum $[129,130]$. Although this correlation is most probably not due to a differing microbial composition and rather due to various confounders, such as gestational age and birth weight [130], it is still important to note that emergency c-sections bear an intrinsic risk for the offspring developing ADHD.

Additionally, it has become increasingly clear to what extent prematurity plays a role in the development of ADHD. As the GI-tract and its colonization with bacteria are still underdeveloped, the microbiome shows lower levels of neuroprotective Lactobacillus [144]. Nonetheless, this decrease of the 
genus has not yet been directly associated with the development of ADHD. Much more important seems to be the combination of premature infants having underdeveloped brain structures and an immature immune system resulting in being more prone to neuronal cell death and infections that promote neuroinflammation, and finally influence the neurodevelopment. It is difficult to deduce the exact impact of microbial changes in preterms on the development of ADHD, as there are numerous confounders [153]. Thus, future studies should elucidate and concentrate on levels of pro-inflammatory cytokines in neonates and determine the extent to which underdeveloped brain structures influence the development of ADHD. Once these have been thoroughly understood, one can assess in what way the microbiome plays a role in the pathophysiology of prenates having a higher prevalence of ADHD. As the topic of this literature review is relatively new, only a limited number of studies examining the link between ADHD and the microbiota could be found. Hence, it was challenging to draw concrete conclusions from the scarce available data. A solid conclusion will require future investigations enrolling larger populations with defined pathologies to be able to analyze the study outcomes using robust statistical analysis. Finally, it is important that future trials use standardized methodologies for an unambiguous comparison of the outcomes and results. This literature review has made it clear that certain factors are associated with ADHD, while simultaneously changing the guts microbiome. Nevertheless, it remains yet to be determined to what extent the composition of the microbiome in the gut influences the development of ADHD.

\section{Conclusions}

To determine to what extent the microbiome plays a role in the pathophysiology of ADHD, further studies are needed. We discussed several triggers that have been associated with ADHD, how these correlate with an altered microbial composition, and thus, how various microbes might act as possible biomarkers for ADHD. Further research, on the microbial composition of ADHD patients using large, well-diagnosed cohorts is needed in order to find future conclusive biomarkers and therapeutic methods to treat ADHD.

Author Contributions: Conceptualization, S.B.-L. and M.H.M.; Methodology, S.B.-L. and M.H.M.; Validation, M.H.M.; Formal Analysis, S.B.-L., and M.H.M.; Investigation, S.B.-L., and M.H.M., Resources, S.B.-L. and M.H.M.; Data curation, S.B.-L.; Writing-Original Draft Preparation, S.B.-L.; Writing-Review and Editing, S.B.-L. and M.H.M.; Visualization, S.B.-L.; Supervision, M.H.M.; Project Administration, M.H.M. and S.B.-L.

Funding: This research received no external funding.

Acknowledgments: We thank David Wolfer for helpful discussions and for critically reading this manuscript.

Conflicts of Interest: The authors declare no conflict of interest.

\section{References}

1. Thursby, E.; Juge, N. Introduction to the human gut microbiota. Biochem. J. 2017, 474, 1823-1836. [CrossRef] [PubMed]

2. Sender, R.; Fuchs, S.; Milo, R. Revised Estimates for the Number of Human and Bacteria Cells in the Body. PLoS Biol. 2016, 14, 1002533. [CrossRef] [PubMed]

3. Bäumler, A.J.; Sperandio, V. Interactions between the microbiota and pathogenic bacteria in the gut. Nature 2016, 535, 85-93. [CrossRef] [PubMed]

4. Mohajeri, M.H.; La Fata, G.; Steinert, R.E.; Weber, P. Relationship between the gut microbiome and brain function. Nutr. Rev. 2018, 76, 481-496. [CrossRef]

5. Mohajeri, M.H.; Brummer, R.J.M.; Rastall, R.A.; Weersma, R.K.; Harmsen, H.J.M.; Faas, M.; Eggersdorfer, M. The role of the microbiome for human health: From basic science to clinical applications. Eur. J. Nutr. 2018, 57, 1-14. [CrossRef]

6. Dinan, T.G.; Cryan, J.F. The Microbiome-Gut-Brain Axis in Health and Disease. Gastroenterol. Clin. N. Am. 2017, 46, 77-89. [CrossRef] 
7. Cotillard, A.; ANR MicroObes consortium; Kennedy, S.P.; Kong, L.C.; Prifti, E.; Pons, N.; Le Chatelier, E.; Almeida, M.; Quinquis, B.; Levenez, F.; et al. Dietary intervention impact on gut microbial gene richness. Nature 2013, 500, 585-588. [CrossRef]

8. Stower, H. Depression linked to the microbiome. Nat. Med. 2019, 25, 358. [CrossRef]

9. Gerhardt, S.; Mohajeri, M.H. Changes of Colonic Bacterial Composition in Parkinson's Disease and Other Neurodegenerative Diseases. Nutrients 2018, 10, 708. [CrossRef]

10. Dickerson, F.; Severance, E.; Yolken, R. The microbiome, immunity, and schizophrenia and bipolar disorder. Brain Behav. Immun. 2017, 62, 46-52. [CrossRef]

11. Srikantha, P.; Mohajeri, M.H. The Possible Role of the Microbiota-Gut-Brain-Axis in Autism Spectrum Disorder. Int. J. Mol. Sci. 2019, 20, 2115. [CrossRef] [PubMed]

12. Borre, Y.E.; O'Keeffe, G.W.; Clarke, G.; Stanton, C.; Dinan, T.G.; Cryan, J.F. Microbiota and neurodevelopmental windows: Implications for brain disorders. Trends Mol. Med. 2014, 20, 509-518. [CrossRef] [PubMed]

13. Association, A.P. Diagnostic and Statistical Manual of Mental Disorders; American Psychiatric Pub: Washington, DC, USA, 2013.

14. Polanczyk, G.; De Lima, M.S.; Horta, B.L.; Biederman, J.; Rohde, L.A. The Worldwide Prevalence of ADHD: A Systematic Review and Metaregression Analysis. Am. J. Psychiatry 2007, 164, 942-948. [CrossRef] [PubMed]

15. Thomas, R.; Sanders, S.; Doust, J.; Beller, E.; Glasziou, P. Prevalence of Attention-Deficit/Hyperactivity Disorder: A Systematic Review and Meta-analysis. Pediatrics 2015, 135, e994-e1001. [CrossRef]

16. Wender, P.H.; Wolf, L.E.; Wasserstein, J. Adults with ADHD. An overview. Ann. N. Y. Acad. Sci. 2001, 931, 1-16. [CrossRef]

17. Wilens, T.E.; Biederman, J.; Faraone, S.V.; Martelon, M.; Westerberg, D.; Spencer, T.J. Presenting ADHD symptoms, subtypes, and comorbid disorders in clinically referred adults with ADHD. J. Clin. Psychiatry 2009, 70, 1557-1562. [CrossRef]

18. Ding, H.T.; Taur, Y.; Walkup, J.T. Gut Microbiota and Autism: Key Concepts and Findings. J. Autism. Dev. Disord. 2017, 47, 480-489. [CrossRef]

19. Rescigno, M. Intestinal microbiota and its effects on the immune system. Cell. Microbiol. 2014, 16, 1004-1013. [CrossRef]

20. Bora, S.A.; Kennett, M.J.; Smith, P.B.; Patterson, A.D.; Cantorna, M.T. The Gut Microbiota Regulates Endocrine Vitamin D Metabolism through Fibroblast Growth Factor. Front. Immunol. 2018, 9, 408. [CrossRef]

21. Macfarlane, S.; Macfarlane, G.T. Regulation of short-chain fatty acid production. Proc. Nutr. Soc. 2003, 62, 67-72. [CrossRef]

22. Dethlefsen, L.; Eckburg, P.B.; Bik, E.M.; Relman, D.A. Assembly of the human intestinal microbiota. Trends Ecol. Evol. 2006, 21, 517-523. [CrossRef] [PubMed]

23. Douglas-Escobar, M.; Elliott, E.; Neu, J. Effect of Intestinal Microbial Ecology on the Developing Brain. JAMA Pediatr. 2013, 167, 374. [CrossRef] [PubMed]

24. Goodrich, J.K.; Davenport, E.R.; Waters, J.L.; Clark, A.G.; Ley, R.E. Cross-species comparisons of host genetic associations with the microbiome. Science 2016, 352, 532-535. [CrossRef] [PubMed]

25. Carmody, R.N.; Gerber, G.K.; Luevano, J.M.; Gatti, D.M.; Somes, L.; Svenson, K.L.; Turnbaugh, P.J. Diet dominates host genotype in shaping the murine gut microbiota. Cell Host Microbe 2015, 17, 72-84. [CrossRef]

26. Bik, E.M. The Hoops, Hopes, and Hypes of Human Microbiome Research. Yale J. Boil. Med. 2016, 89, 363-373.

27. Buie, T. Potential Etiologic Factors of Microbiome Disruption in Autism. Clin. Ther. 2015, 37, 976-983. [CrossRef]

28. Koenig, J.E.; Spor, A.; Scalfone, N.; Fricker, A.D.; Stombaugh, J.; Knight, R.; Angenent, L.T.; Ley, R.E. Succession of microbial consortia in the developing infant gut microbiome. Proc. Natl. Acad. Sci. USA 2011, 108, 4578-4585. [CrossRef]

29. Collado, M.C.; Rautava, S.; Aakko, J.; Isolauri, E.; Salminen, S. Human gut colonisation may be initiated in utero by distinct microbial communities in the placenta and amniotic fluid. Sci. Rep. 2016, 6, 23129. [CrossRef]

30. MacIntyre, D.A.; Chandiramani, M.; Lee, Y.S.; Kindinger, L.; Smith, A.; Angelopoulos, N.; Lehne, B.; Arulkumaran, S.; Brown, R.; Teoh, T.G.; et al. The vaginal microbiome during pregnancy and the postpartum period in a European population. Sci. Rep. 2015, 5, 8988. [CrossRef]

31. Aagaard, K.; Ma, J.; Antony, K.M.; Ganu, R.; Petrosino, J.; Versalovic, J. The Placenta Harbors a Unique Microbiome. Sci. Transl. Med. 2014, 6, 237ra65. [CrossRef] 
32. Human Microbiome Jumpstart Reference Strains Consortium; Nelson, K.E.; Weinstock, G.M.; Highlander, S.K.; Worley, K.C.; Creasy, H.H.; Wortman, J.R.; Rusch, D.B.; Mitreva, M.; Sodergren, E.; et al. A catalog of reference genomes from the human microbiome. Science 2010, 328, 994-999. [CrossRef] [PubMed]

33. Brotman, R.M. Vaginal microbiome and sexually transmitted infections: An epidemiologic perspective. J. Clin. Investig. 2011, 121, 4610-4617. [CrossRef] [PubMed]

34. Dogra, S.; Sakwinska, O.; Soh, S.-E.; Ngom-Bru, C.; Brück, W.M.; Berger, B.; Brüssow, H.; Karnani, N.; Lee, Y.S.; Yap, F.; et al. Rate of establishing the gut microbiota in infancy has consequences for future health. Gut Microbes 2015, 6, 321-325. [CrossRef] [PubMed]

35. Bäckhed, F.; Roswall, J.; Peng, Y.; Feng, Q.; Jia, H.; Kovatcheva-Datchary, P.; Li, Y.; Xia, Y.; Xie, H.; Zhong, H.; et al. Dynamics and Stabilization of the Human Gut Microbiome during the First Year of Life. Cell Host Microbe 2015, 17, 852. [CrossRef]

36. Latorre, R.; Sternini, C.; De Giorgio, R.; Greenwood-Van Meerveld, B. Enteroendocrine cells: A review of their role in brain-gut communication. Neurogastroenterol. Motil. 2016, 28, 620-630. [CrossRef]

37. Mayer, E.A.; Knight, R.; Mazmanian, S.K.; Cryan, J.F.; Tillisch, K. Gut microbes and the brain: Paradigm shift in neuroscience. J. Neurosci. 2014, 34, 15490-15496. [CrossRef]

38. Cryan, J.F.; Dinan, T.G. Mind-altering microorganisms: The impact of the gut microbiota on brain and behaviour. Nat. Rev. Neurosci. 2012, 13, 701-712. [CrossRef]

39. Shaw, P.; Stringaris, A.; Nigg, J.; Leibenluft, E. Emotion dysregulation in attention deficit hyperactivity disorder. Am. J. Psychiatry 2014, 171, 276-293. [CrossRef]

40. Cortese, S.; Brown, T.E.; Corkum, P.; Gruber, R.; O’Brien, L.M.; Stein, M.; Weiss, M.; Owens, J. Assessment and Management of Sleep Problems in Youths With Attention-Deficit/Hyperactivity Disorder. J. Am. Acad. Child. Adolesc. Psychiatry 2013, 52, 784-796. [CrossRef]

41. Baird, A.L.; Coogan, A.N.; Siddiqui, A.; Donev, R.M.; Thome, J. Adult attention-deficit hyperactivity disorder is associated with alterations in circadian rhythms at the behavioural, endocrine and molecular levels. Mol. Psychiatry 2012, 17, 988-995. [CrossRef]

42. Van Lenten, S.A.; Doane, L.D. Examining multiple sleep behaviors and diurnal salivary cortisol and alpha-amylase: Within- and between-person associations. Psychoneuroendocrinology 2016, 68, 100-110. [CrossRef] [PubMed]

43. Tsigos, C.; Chrousos, G.P. Hypothalamic-pituitary-adrenal axis, neuroendocrine factors and stress. J. Psychosom. Res. 2002, 53, 865-871. [CrossRef]

44. Freitag, C.M.; Hänig, S.; Palmason, H.; Meyer, J.; Wüst, S.; Seitz, C. Cortisol awakening response in healthy children and children with ADHD: Impact of comorbid disorders and psychosocial risk factors. Psychoneuroendocrinology 2009, 34, 1019-1028. [CrossRef] [PubMed]

45. Blomqvist, M.; Holmberg, K.; Lindblad, F.; Fernell, E.; Ek, U.; Dahllöf, G. Salivary cortisol levels and dental anxiety in children with attention deficit hyperactivity disorder. Eur. J. Oral Sci. 2007, 115, 1-6. [CrossRef]

46. Corominas-Roso, M.; Palomar, G.; Ferrer, R.; Real, A.; Nogueira, M.; Corrales, M.; Casas, M.; Ramos-Quiroga, J.A. Cortisol Response to Stress in Adults with Attention Deficit Hyperactivity Disorder. Int. J. Neuropsychopharmacol. 2015, 18, 18. [CrossRef]

47. Lackschewitz, H.; Hüther, G.; Kröner-Herwig, B. Physiological and psychological stress responses in adults with attention-deficit/hyperactivity disorder (ADHD). Psychoneuroendocrinology 2008, 33, 612-624. [CrossRef]

48. Principi, N.; Esposito, S. Gut microbiota and central nervous system development. J. Infect. 2016, 73, 536-546. [CrossRef]

49. Sato, K. Effects of Microglia on Neurogenesis. Glia 2015, 63, 1394-1405. [CrossRef]

50. Erny, D.; De Angelis, A.L.H.; Jaitin, D.; Wieghofer, P.; Staszewski, O.; David, E.; Keren-Shaul, H.; Mahlakoiv, T.; Jakobshagen, K.; Buch, T.; et al. Host microbiota constantly control maturation and function of microglia in the CNS. Nat. Neurosci. 2015, 18, 965-977. [CrossRef]

51. Critchley, H.D.; Eccles, J.; Garfinkel, S.N. Interaction between cognition, emotion, and the autonomic nervous system. Stroke 2013, 117, 59-77.

52. Koopman, F.A.; Stoof, S.P.; Straub, R.H.; Van Maanen, M.A.; Vervoordeldonk, M.J.; Tak, P.P. Restoring the Balance of the Autonomic Nervous System as an Innovative Approach to the Treatment of Rheumatoid Arthritis. Mol. Med. 2011, 17, 937-948. [CrossRef] [PubMed]

53. Lyte, M. Microbial Endocrinology and the Microbiota-Gut-Brain Axis. Adv. Exp. Med. Biol. 2014, 817, 3-24. [PubMed] 
54. Negrao, B.L.; Bipath, P.; Van Der Westhuizen, D.; Viljoen, M. Autonomic Correlates at Rest and during Evoked Attention in Children with Attention-Deficit/Hyperactivity Disorder and Effects of Methylphenidate. Neuropsychobiology 2011, 63, 82-91. [CrossRef] [PubMed]

55. Musser, E.D.; Backs, R.W.; Schmitt, C.F.; Ablow, J.C.; Measelle, J.R.; Nigg, J.T. Emotion regulation via the autonomic nervous system in children with attention-deficit/hyperactivity disorder (ADHD). J. Abnorm. Child. Psychol. 2011, 39, 841-852. [CrossRef] [PubMed]

56. Tandon, M.; Pergjika, A. Attention Deficit Hyperactivity Disorder in Preschool-Age Children. Child Adolesc. Psychiatr Clin. N. Am. 2017, 26, 523-538. [CrossRef] [PubMed]

57. Willcutt, E.G.; Nigg, J.T.; Pennington, B.F.; Solanto, M.V.; Rohde, L.A.; Tannock, R.; Loo, S.K.; Carlson, C.L.; McBurnett, K.; Lahey, B.B. Validity of DSM-IV attention deficit/hyperactivity disorder symptom dimensions and subtypes. J. Abnorm. Psychol. 2012, 121, 991-1010. [CrossRef]

58. Thapar, A.; Cooper, M.; Eyre, O.; Langley, K. What have we learnt about the causes of ADHD? J. Child. Psychol. Psychiatry 2013, 54, 3-16. [CrossRef]

59. Starobrat-Hermelin, B. The effect of deficiency of selected bioelements on hyperactivity in children with certain specified mental disorders. Ann. Acad. Med. Stetin. 1998, 44, 297-314.

60. Sciberras, E.; Mulraney, M.; Silva, D.; Coghill, D. Prenatal Risk Factors and the Etiology of ADHD—Review of Existing Evidence. Curr. Psychiatry Rep. 2017, 19, 1. [CrossRef]

61. Dias, T.G.C.; Kieling, C.; Graeff-Martins, A.S.; Moriyama, T.S.; Rohde, L.A.; Polanczyk, G.V. Developments and challenges in the diagnosis and treatment of ADHD. Braz. J. Psychiatry 2013, 35, S40-S50. [CrossRef]

62. Sharma, A.; Couture, J. A review of the pathophysiology, etiology, and treatment of attention-deficit hyperactivity disorder (ADHD). Ann. Pharmacother. 2014, 48, 209-225. [CrossRef] [PubMed]

63. Daubner, S.C.; Le, T.; Wang, S. Tyrosine hydroxylase and regulation of dopamine synthesis. Arch. Biochem. Biophys. 2011, 508, 1-12. [CrossRef] [PubMed]

64. Arias-Carrión, O.; Stamelou, M.; Murillo-Rodriguez, E.; Menéndez-González, M.; Pöppel, E. Dopaminergic reward system: A short integrative review. Int. Arch. Med. 2010, 3, 24. [CrossRef] [PubMed]

65. Dougherty, D.D.; Bonab, A.A.; Spencer, T.J.; Rauch, S.L.; Madras, B.K.; Fischman, A.J. Dopamine transporter density in patients with attention deficit hyperactivity disorder. Lancet 1999, 354, 2132-2133. [CrossRef]

66. Tong, J.; Meyer, J.H.; Furukawa, Y.; Boileau, I.; Chang, L.-J.; Wilson, A.A.; Houle, S.; Kish, S.J. Distribution of monoamine oxidase proteins in human brain: Implications for brain imaging studies. Br. J. Pharmacol. 2013, 33, 863-871. [CrossRef]

67. Seiden, L.S.; Sabol, K.E.; Ricaurte, G.A. Amphetamine: Effects on catecholamine systems and behavior. Annu. Rev. Pharmacol. Toxicol. 1993, 33, 639-677. [CrossRef]

68. Strandwitz, P. Neurotransmitter modulation by the gut microbiota. Brain Res. 2018, 1693, 128-133. [CrossRef]

69. Aarts, E.; Ederveen, T.H.A.; Naaijen, J.; Zwiers, M.P.; Boekhorst, J.; Timmerman, H.M.; Smeekens, S.P.; Netea, M.G.; Buitelaar, J.K.; Franke, B.; et al. Gut microbiome in ADHD and its relation to neural reward anticipation. PLOS ONE 2017, 12, e0183509. [CrossRef]

70. Lou, H. Dopamine precursors and brain function in phenylalanine hydroxylase deficiency. Acta Paediatr. 1994, 83, 86-88. [CrossRef]

71. Scheres, A.; Milham, M.P.; Knutson, B.; Castellanos, F.X. Ventral Striatal Hyporesponsiveness During Reward Anticipation in Attention-Deficit/Hyperactivity Disorder. Boil. Psychiatry 2007, 61, 720-724. [CrossRef]

72. Ming, X.; Chen, N.; Ray, C.; Brewer, G.; Kornitzer, J.; Steer, R.A. A Gut Feeling: A Hypothesis of the Role of the Microbiome in Attention-Deficit/Hyperactivity Disorders. Child Neurol. Open 2018, 5, 2329048X18786799. [CrossRef] [PubMed]

73. Antshel, K.M.; Waisbren, S.E. Developmental timing of exposure to elevated levels of phenylalanine is associated with ADHD symptom expression. J. Abnorm. Child Psychol. 2003, 31, 565-574. [CrossRef] [PubMed]

74. Baker, G.; Bornstein, R.; Rouget, A.; Ashton, S.; Van Muyden, J.; Coutts, R. Phenylethylaminergic mechanisms in attention-deficit disorder. Boil. Psychiatry 1991, 29, 15-22. [CrossRef]

75. Bornstein, R.; Baker, G.B.; Carroll, A.; King, G.; Wong, J.T.; Douglass, A.B. Plasma amino acids in attention deficit disorder. Psychiatry Res. 1990, 33, 301-306. [CrossRef]

76. Bergwerff, C.E.; Luman, M.; Blom, H.J.; Oosterlaan, J. No Tryptophan, Tyrosine and Phenylalanine Abnormalities in Children with Attention-Deficit/Hyperactivity Disorder. PLoS ONE 2016, 11, e0151100. [CrossRef] 
77. O'Mahony, S.; Clarke, G.; Borre, Y.; Dinan, T.; Cryan, J.; Dinan, T. Serotonin, tryptophan metabolism and the brain-gut-microbiome axis. Behav. Brain Res. 2015, 277, 32-48. [CrossRef]

78. Dinan, T.G.; Stanton, C.; Cryan, J.F. Psychobiotics: A Novel Class of Psychotropic. Boil. Psychiatry 2013, 74, 720-726. [CrossRef]

79. Mawe, G.M.; Hoffman, J.M. Serotonin signalling in the gut-Functions, dysfunctions and therapeutic targets. Nat. Rev. Gastroenterol. Hepatol. 2013, 10, 473-486. [CrossRef]

80. Mechan, A.O.; Fowler, A.; Seifert, N.; Rieger, H.; Wöhrle, T.; Etheve, S.; Wyss, A.; Schüler, G.; Colletto, B.; Kilpert, C.; et al. Monoamine reuptake inhibition and mood-enhancing potential of a specified oregano extract. Br. J. Nutr. 2011, 105, 1150-1163. [CrossRef]

81. Banerjee, E.; Nandagopal, K. Does serotonin deficit mediate susceptibility to ADHD? Neurochem. Int. 2015, 82, 52-68. [CrossRef]

82. Johansson, J.; Landgren, M.; Fernell, E.; Vumma, R.; Åhlin, A.; Bjerkenstedt, L.; Venizelos, N. Altered tryptophan and alanine transport in fibroblasts from boys with attention-deficit/hyperactivity disorder (ADHD): An in vitro study. Behav. Brain Funct. 2011, 7, 40. [CrossRef] [PubMed]

83. Clarke, G.; Grenham, S.; Scully, P.; Fitzgerald, P.; Moloney, R.D.; Shanahan, F.; Dinan, T.G.; Cryan, J.F. The microbiome-gut-brain axis during early life regulates the hippocampal serotonergic system in a sex-dependent manner. Mol. Psychiatry 2013, 18, 666-673. [CrossRef] [PubMed]

84. Badawy, A.A. Tryptophan metabolism, disposition and utilization in pregnancy. Biosci. Rep. 2015, 35, e00261. [CrossRef] [PubMed]

85. Wu, H.Q.; Okuyama, M.; Kajii, Y.; Pocivavsek, A.; Bruno, J.P.; Schwarcz, R. Targeting kynurenine aminotransferase II in psychiatric diseases: Promising effects of an orally active enzyme inhibitor. Schizophr. Bull. 2014, 40, S152-S158. [CrossRef] [PubMed]

86. Aarsland, T.I.M.; Landaas, E.T.; Hegvik, T.-A.; Ulvik, A.; Halmøy, A.; Ueland, P.M.; Haavik, J. Serum concentrations of kynurenines in adult patients with attention-deficit hyperactivity disorder (ADHD): A case-control study. Behav. Brain Funct. 2015, 11, 36. [CrossRef] [PubMed]

87. Maes, M.; Mihaylova, I.; De Ruyter, M.; Kubera, M.; Bosmans, E. The immune effects of TRYCATs (tryptophan catabolites along the IDO pathway): Relevance for depression- and other conditions characterized by tryptophan depletion induced by inflammation. Neuro Endocrinol. Lett. 2007, 28, 826-831. [PubMed]

88. Moroni, F.; Cozzi, A.; Sili, M.; Mannaioni, G. Kynurenic acid: A metabolite with multiple actions and multiple targets in brain and periphery. J. Neural Transm. 2012, 119, 133-139. [CrossRef]

89. Neale, S.A.; Copeland, C.S.; Uebele, V.N.; Thomson, F.J.; Salt, T.E. Modulation of Hippocampal Synaptic Transmission by the Kynurenine Pathway Member Xanthurenic Acid and Other VGLUT Inhibitors. Neuropsychopharmacology 2013, 38, 1060-1067. [CrossRef]

90. Cenit, M.C.; Nuevo, I.C.; Codoñer-Franch, P.; Sanz, Y.; Dinan, T.G. Gut microbiota and attention deficit hyperactivity disorder: New perspectives for a challenging condition. Eur. Child. Adolesc. Psychiatry 2017, 8, 429-1092. [CrossRef]

91. Kozak, R.; Campbell, B.M.; Strick, C.A.; Horner, W.; Hoffmann, W.E.; Kiss, T.; Chapin, D.S.; McGinnis, D.; Abbott, A.L.; Roberts, B.M.; et al. Reduction of Brain Kynurenic Acid Improves Cognitive Function. J. Neurosci. 2014, 34, 10592-10602. [CrossRef]

92. Vécsei, L.; Szalárdy, L.; Fülöp, F.; Toldi, J. Kynurenines in the CNS: Recent advances and new questions. Nat. Rev. Drug Discov. 2013, 12, 64-82. [CrossRef] [PubMed]

93. Evangelisti, M.; De Rossi, P.; Rabasco, J.; Donfrancesco, R.; Lionetto, L.; Capi, M.; Sani, G.; Simmaco, M.; Nicoletti, F.; Villa, M.P. Changes in serum levels of kynurenine metabolites in paediatric patients affected by ADHD. Eur. Child. Adolesc. Psychiatry 2017, 26, 1433-1441. [CrossRef] [PubMed]

94. Landaas, E.T.; Aarsland, T.I.; Ulvik, A.; Halmøy, A.; Ueland, P.M.; Haavik, J. Vitamin levels in adults with ADHD. BJPsych Open 2016, 2, 377-384. [CrossRef] [PubMed]

95. Dolina, S.; Margalit, D.; Malitsky, S.; Rabinkov, A. Attention-deficit hyperactivity disorder (ADHD) as a pyridoxine-dependent condition: Urinary diagnostic biomarkers. Med. Hypotheses 2014, 82, 111-116. [CrossRef]

96. Said, Z.M.; Subramanian, V.S.; Vaziri, N.D.; Said, H.M. T1881 Pyridoxine Uptake By Colonocytes: A Specific and Regulated Carrier-Mediated Process. Am. J. Physiol. Cell Physiol. 2008, 294, C1192-C1197. [CrossRef] 
97. Gagliardi, A.; Totino, V.; Cacciotti, F.; Iebba, V.; Neroni, B.; Bonfiglio, G.; Trancassini, M.; Passariello, C.; Pantanella, F.; Schippa, S. Rebuilding the Gut Microbiota Ecosystem. Int. J. Environ. Res. Public Health 2018, 15, 1679. [CrossRef]

98. Fond, G.; Boukouaci, W.; Chevalier, G.; Regnault, A.; Eberl, G.; Hamdani, N.; Dickerson, F.; MacGregor, A.; Boyer, L.; Dargel, A.; et al. The "psychomicrobiotic": Targeting microbiota in major psychiatric disorders: A systematic review. Pathol. Boil. 2015, 63, 35-42. [CrossRef]

99. Saltzman, E.T.; Palacios, T.; Thomsen, M.; Vitetta, L. Intestinal Microbiome Shifts, Dysbiosis, Inflammation, and Non-alcoholic Fatty Liver Disease. Front. Microbiol. 2018, 9, 61. [CrossRef]

100. Varatharaj, A.; Galea, I. The blood-brain barrier in systemic inflammation. Brain Behav. Immun. 2017, 60, 1-12. [CrossRef]

101. Verlaet, A.A.J.; Noriega, D.B.; Hermans, N.; Savelkoul, H.F.J. Nutrition, immunological mechanisms and dietary immunomodulation in ADHD. Eur. Child. Adolesc. Psychiatry 2014, 23, 519-529. [CrossRef]

102. Mitchell, R.H.; Goldstein, B.I. Inflammation in children and adolescents with neuropsychiatric disorders: A systematic review. J. Am. Acad. Child Adolesc. Psychiatry 2014, 53, 274-296. [CrossRef] [PubMed]

103. Di Cesare, A.; Di Meglio, P.; Nestle, F.O. A role for Th17 cells in the immunopathogenesis of atopic dermatitis? J. Investig. Dermatol. 2008, 128, 2569-2571. [CrossRef] [PubMed]

104. Chen, M.H.; Su, T.P.; Chen, Y.S.; Hsu, J.W.; Huang, K.L.; Chang, W.H.; Bai, Y.M. Attention deficit hyperactivity disorder, tic disorder, and allergy: Is there a link? A nationwide population-based study. J. Child. Psychol. Psychiatry 2013, 54, 545-551. [CrossRef] [PubMed]

105. Tsai, M.C.; Lin, H.K.; Lin, C.H.; Fu, L.S. Prevalence of attention deficit/hyperactivity disorder in pediatric allergic rhinitis: A nationwide population-based study. Allergy Asthma Proc. 2011, 32, 41-46. [CrossRef] [PubMed]

106. Genuneit, J.; Braig, S.; Brandt, S.; Wabitsch, M.; Florath, I.; Brenner, H.; Rothenbacher, D. Infant atopic eczema and subsequent attention-deficit/hyperactivity disorder-a prospective birth cohort study. Pediatr. Allergy Immunol. 2014, 25, 51-56. [CrossRef] [PubMed]

107. Lynch, S.V. Gut Microbiota and Allergic Disease. New Insights. Ann. Am. Thorac. Soc. 2016, 13, S51-S54.

108. Martínez,I.; Lattimer, J.M.; Hubach, K.L.; Case,J.A.; Yang, J.; Weber, C.G.; Louk,J.A.; Rose, D.J.; Kyureghian, G.; Peterson, D.A.; et al. Gut microbiome composition is linked to whole grain-induced immunological improvements. ISME J. 2013, 7, 269-280. [CrossRef]

109. Christian, L.M.; Galley, J.D.; Hade, E.M.; Schoppe-Sullivan, S.; Kamp Dush, C.; Bailey, M.T. Gut microbiome composition is associated with temperament during early childhood. Brain Behav. Immun. 2015, 45, 118-127. [CrossRef]

110. Buske-Kirschbaum, A.; Schmitt, J.; Plessow, F.; Romanos, M.; Weidinger, S.; Roessner, V. Psychoendocrine and psychoneuroimmunological mechanisms in the comorbidity of atopic eczema and attention deficit/hyperactivity disorder. Psychoneuroendocrinology 2013, 38, 12-23. [CrossRef]

111. Jiang, H.-Y.; Zhou, Y.-Y.; Zhou, G.-L.; Li, Y.-C.; Yuan, J.; Li, X.-H.; Ruan, B. Gut microbiota profiles in treatment-naïve children with attention deficit hyperactivity disorder. Behav. Brain Res. 2018, 347, 408-413. [CrossRef]

112. Marshall, P. Attention deficit disorder and allergy: A neurochemical model of the relation between the illnesses. Psychol. Bull. 1989, 106, 434-446. [CrossRef]

113. Van Der Schans, J.; De Vries, T.W.; Hak, E.; Hoekstra, P.J.; Çiçek, R. Association of atopic diseases and attention-deficit/hyperactivity disorder: A systematic review and meta-analyses. Neurosci. Biobehav. Rev. 2017, 74, 139-148. [CrossRef] [PubMed]

114. Schmitt, J.; Romanos, M.; Meurer, M.; Kirch, W. Atopic Eczema and Attention-Deficit/Hyperactivity Disorder in a Population-Based Sample of Children and Adolescents. JAMA 2009, 301, 724. [CrossRef] [PubMed]

115. Strachan, D.; Sibbald, B.; Weiland, S.; Aït-Khaled, N.; Anabwani, G.; Anderson, H.R.; Asher, M.I.; Beasley, R.; Björkstén, B.; Burr, M.; et al. Worldwide variations in prevalence of symptoms of allergic rhinoconjunctivitis in children: The International Study of Asthma and Allergies in Childhood (ISAAC). Pediatr. Allergy Immunol. 1997, 8, 161-176. [CrossRef] [PubMed]

116. Leung, D.Y.; Bieber, T. Atopic dermatitis. Lancet 2003, 361, 151-160. [CrossRef]

117. Novak, N. Immune mechanisms leading to atopic dermatitis. J. Allergy Clin. Immunol. 2003, 112, S128-S139. [CrossRef] 
118. Penders, J.; Thijs, C.; van den Brandt, P.A.; Kummeling, I.; Snijders, B.; Stelma, F.; Adams, H.; van Ree, R.; Stobberingh, E.E. Gut microbiota composition and development of atopic manifestations in infancy: The KOALA Birth Cohort Study. Gut 2007, 56, 661-667. [CrossRef]

119. Qiu, X.; Zhang, M.; Yang, X.; Hong, N.; Yu, C. Faecalibacterium prausnitzii upregulates regulatory T cells and anti-inflammatory cytokines in treating TNBS-induced colitis. J. Crohns Colitis 2013, 7, e558-e568. [CrossRef]

120. Quévrain, E.; Maubert, M.A.; Michon, C.; Chain, F.; Marquant, R.; Tailhades, J.; Miquel, S.; Carlier, L.; Bermúdez-Humarán, L.G.; Pigneur, B.; et al. Identification of an anti-inflammatory protein from Faecalibacterium prausnitzii, a commensal bacterium deficient in Crohn's disease. Gut 2016, 65, 415-425.

121. Dominguez-Bello, M.G.; Costello, E.K.; Contreras, M.; Magris, M.; Hidalgo, G.; Fierer, N.; Knight, R. Delivery mode shapes the acquisition and structure of the initial microbiota across multiple body habitats in newborns. Proc. Natl. Acad. Sci. USA 2010, 107, 11971-11975. [CrossRef]

122. Penders, J.; Thijs, C.; Vink, C.; Stelma, F.F.; Snijders, B.; Kummeling, I.; Brandt, P.A.V.D.; Stobberingh, E.E. Factors Influencing the Composition of the Intestinal Microbiota in Early Infancy. Pediatrics 2006, 118, 511-521. [CrossRef] [PubMed]

123. Jakobsson, H.E.; Abrahamsson, T.R.; Jenmalm, M.C.; Harris, K.; Quince, C.; Jernberg, C.; Björkstén, B.; Engstrand, L.; Andersson, A.F. Decreased gut microbiota diversity, delayed Bacteroidetes colonisation and reduced Th1 responses in infants delivered by caesarean section. Gut 2014, 63, 559-566. [CrossRef] [PubMed]

124. Boksa, P.; El-Khodor, B.F. Birth insult interacts with stress at adulthood to alter dopaminergic function in animal models: Possible implications for schizophrenia and other disorders. Neurosci. Biobehav. Rev. 2003, 27, 91-101. [CrossRef]

125. Salas, M.; Hotman, A.; Stricker, B.H. Confounding by Indication: An Example of Variation in the Use of Epidemiologic Terminology. Am. J. Epidemiol. 1999, 149, 981-983. [CrossRef] [PubMed]

126. Ketzer, C.R.; Gallois, C.; Martinez, A.L.; Rohde, L.A.; Schmitz, M. Is there an association between perinatal complications and attention-deficit/hyperactivity disorder-inattentive type in children and adolescents? Braz. J. Psychiatry 2012, 34, 321-328. [CrossRef] [PubMed]

127. Silva, D.; Colvin, L.; Hagemann, E.; Bower, C. Environmental risk factors by gender associated with attention-deficit/hyperactivity disorder. Pediatrics 2014, 133, e14-e22. [CrossRef] [PubMed]

128. Curran, E.A.; O’Neill, S.M.; Cryan, J.F.; Kenny, L.C.; Dinan, T.G.; Khashan, A.S.; Kearney, P.M. Research review: Birth by caesarean section and development of autism spectrum disorder and attention-deficit/hyperactivity disorder: A systematic review and meta-analysis. J. Child Psychol. Psychiatry 2015, 56, 500-508. [CrossRef]

129. Curran, E.A.; Khashan, A.S.; Dalman, C.; Kenny, L.C.; Cryan, J.F.; Dinan, T.G.; Kearney, P.M. Obstetric mode of delivery and attention-deficit/hyperactivity disorder: A sibling-matched study. Int. J. Epidemiol. 2016, 45, 532-542. [CrossRef]

130. Axelsson, P.B.; Clausen, T.D.; Petersen, A.H.; Hageman, I.; Pinborg, A.; Kessing, L.V.; Bergholt, T.; Rasmussen, S.C.; Keiding, N.; Løkkegaard, E.C.L. Investigating the effects of cesarean delivery and antibiotic use in early childhood on risk of later attention deficit hyperactivity disorder. J. Child Psychol. Psychiatry 2019, 60, 151-159. [CrossRef]

131. Curran, E.A.; Cryan, J.F.; Kenny, L.C.; Dinan, T.G.; Kearney, P.M.; Khashan, A.S. Obstetrical Mode of Delivery and Childhood Behavior and Psychological Development in a British Cohort. J. Autism Dev. Disord. 2016, 46, 603-614. [CrossRef]

132. Li, J.; Olsen, J.; Vestergaard, M.; Obel, C. Attention-deficit/hyperactivity disorder in the offspring following prenatal maternal bereavement: A nationwide follow-up study in Denmark. Eur. Child. Adolesc. Psychiatry 2010, 19, 747-753. [CrossRef] [PubMed]

133. Van den Bergh, B.R.; Marcoen, A. High antenatal maternal anxiety is related to ADHD symptoms, externalizing problems, and anxiety in 8- and 9-year-olds. Child Dev. 2004, 75, 1085-1097. [CrossRef] [PubMed]

134. Grizenko, N.; Shayan, Y.R.; Polotskaia, A.; Ter-Stepanian, M.; Joober, R. Relation of maternal stress during pregnancy to symptom severity and response to treatment in children with ADHD. J. Psychiatry Neurosci. 2008, 33, 10-16. [PubMed]

135. Jašarević, E.; Howerton, C.L.; Howard, C.D.; Bale, T.L. Alterations in the Vaginal Microbiome by Maternal Stress Are Associated With Metabolic Reprogramming of the Offspring Gut and Brain. Endocrinology 2015, 156, 3265-3276. [CrossRef] [PubMed]

136. Galley, J.D.; Bailey, M.T. Impact of stressor exposure on the interplay between commensal microbiota and host inflammation. Gut Microbes 2014, 5, 390-396. [CrossRef] [PubMed] 
137. Barrett, E.; Ross, R.P.; O'Toole, P.W.; Fitzgerald, G.F.; Stanton, C. $\gamma$-Aminobutyric acid production by culturable bacteria from the human intestine. J. Appl. Microbiol. 2012, 113, 411-417. [CrossRef]

138. Edden, R.A.E.; Crocetti, D.; Zhu, H.; Gilbert, D.L.; Mostofsky, S.H. Reduced GABA concentration in attention-deficit/hyperactivity disorder. Arch. Gen. Psychiatry 2012, 69, 750-753. [CrossRef]

139. Bollmann, S.; Ghisleni, C.; Poil, S.-S.; Martin, E.; Ball, J.; Eich-Höchli, D.; Edden, R.A.E.; Klaver, P.; Michels, L.; Brandeis, D.; et al. Developmental changes in gamma-aminobutyric acid levels in attention-deficit/hyperactivity disorder. Transl. Psychiatry 2015, 5, e589. [CrossRef]

140. Sumner, P.; Edden, R.A.E.; Bompas, A.; Evans, C.J.; Singh, K.D. More GABA, less distraction: A neurochemical predictor of motor decision speed. Nat. Neurosci. 2010, 13, 825-827. [CrossRef]

141. Wiebking, C.; Duncan, N.W.; Tiret, B.; Hayes, D.J.; Marjaǹska, M.; Doyon, J.; Bajbouj, M.; Northoff, G. GABA in the insula-A predictor of the neural response to interoceptive awareness. Neuroimage 2014, 86, 10-18. [CrossRef]

142. Pärtty, A.; Kalliomäki, M.; Wacklin, P.; Salminen, S.; Isolauri, E. A possible link between early probiotic intervention and the risk of neuropsychiatric disorders later in childhood: A randomized trial. Pediatr. Res. 2015, 77, 823-828. [CrossRef]

143. Kalliomäki, M.; Salminen, S.; Arvilommi, H.; Kero, P.; Koskinen, P.; Isolauri, E. Probiotics in primary prevention of atopic disease: A randomised placebo-controlled trial. Lancet 2001, 357, 1076-1079. [CrossRef]

144. Barrett, E.; Kerr, C.; Murphy, K.; O’Sullivan, O.; Ryan, C.A.; Dempsey, E.M.; Murphy, B.P.; O’Toole, P.W.; Cotter, P.D.; Fitzgerald, G.F.; et al. The individual-specific and diverse nature of the preterm infant microbiota. Arch. Dis. Child Fetal Neonatal Ed. 2013, 98, F334-F340. [CrossRef] [PubMed]

145. Bhutta, A.T.; Cleves, M.A.; Casey, P.H.; Cradock, M.M.; Anand, K.J.S. Cognitive and behavioral outcomes of school-aged children who were born preterm: A meta-analysis. JAMA 2002, 288, 728-737. [CrossRef] [PubMed]

146. Johnson, S.; Hollis, C.; Kochhar, P.; Hennessy, E.; Wolke, D.; Marlow, N. Psychiatric disorders in extremely preterm children: Longitudinal finding at age 11 years in the EPICure study. J. Am. Acad. Child Adolesc. Psychiatry 2010, 49, 453-463.e1. [CrossRef]

147. Ask, H.; Gustavson, K.; Ystrom, E.; Havdahl, K.A.; Tesli, M.; Askeland, R.B.; Reichborn-Kjennerud, T. Association of Gestational Age at Birth With Symptoms of Attention-Deficit/Hyperactivity Disorder in Children. JAMA Pediatr. 2018, 172, 749-756. [CrossRef]

148. Chou, I.-C.; Kuo, H.-T.; Chang, J.-S.; Wu, S.-F.; Chiu, H.-Y.; Su, B.-H.; Lin, H.-C. Lack of Effects of Oral Probiotics on Growth and Neurodevelopmental Outcomes in Preterm Very Low Birth Weight Infants. J. Pediatr. 2010, 156, 393-396. [CrossRef]

149. Melville, J.M.; Moss, T.J. The immune consequences of preterm birth. Front. Neurosci. 2013, 7, 79. [CrossRef]

150. Quinn, J.-A.; Munoz, F.M.; Gonik, B.; Frau, L.; Cutland, C.; Mallett-Moore, T.; Kissou, A.; Wittke, F.; Das, M.; Nunes, T.; et al. Preterm birth: Case definition \& guidelines for data collection, analysis, and presentation of immunisation safety data. Vaccine 2016, 34, 6047-6056.

151. Lindström, K.; Lindblad, F.; Hjern, A. Preterm birth and attention-deficit/hyperactivity disorder in schoolchildren. Pediatrics 2011, 127, 858-865. [CrossRef]

152. D'Onofrio, B.M.; Class, Q.A.; Rickert, M.E.; Larsson, H.; Langström, N.; Lichtenstein, P. Preterm birth and mortality and morbidity: A population-based quasi-experimental study. JAMA Psychiatry 2013, 70, 1231-1240. [CrossRef] [PubMed]

153. Farooqi, A.; Hägglöf, B.; Sedin, G.; Gothefors, L.; Serenius, F. Mental Health and Social Competencies of 10to 12-Year-Old Children Born at 23 to 25 Weeks of Gestation in the 1990s: A Swedish National Prospective Follow-up Study. Pediatrics 2007, 120, 118-133. [CrossRef] [PubMed]

154. Sternbach, H.; State, R. Antibiotics: Neuropsychiatric effects and psychotropic interactions. Harv. Rev. Psychiatry 1997, 5, 214-226. [CrossRef] [PubMed]

155. Becattini, S.; Taur, Y.; Pamer, E.G. Antibiotic-Induced Changes in the Intestinal Microbiota and Disease. Trends Mol. Med. 2016, 22, 458-478. [CrossRef] [PubMed]

156. Park, S.; Kim, B.N.; Kim, J.W.; Shin, M.S.; Yoo, H.J.; Cho, S.C. Protective effect of breastfeeding with regard to children's behavioral and cognitive problems. Nutr. J. 2014, 13, 111. [CrossRef] [PubMed]

157. Mimouni-Bloch, A.; Kachevanskaya, A.; Mimouni, F.B.; Shuper, A.; Raveh, E.; Linder, N. Breastfeeding may protect from developing attention-deficit/hyperactivity disorder. Breastfeed Med. 2013, 8, 363-367. [CrossRef] [PubMed] 
158. Stadler, D.D.; Musser, E.D.; Holton, K.F.; Shannon, J.; Nigg, J.T. Recalled Initiation and Duration of Maternal Breastfeeding Among Children with and Without ADHD in a Well Characterized Case-Control Sample. J. Abnorm. Child. Psychol. 2016, 44, 347-355. [CrossRef]

159. Golmirzaei, J.; Namazi, S.; Amiri, S.; Zare, S.; Rastikerdar, N.; Hesam, A.A.; Rahami, Z.; Ghasemian, F.; Namazi, S.S.; Paknahad, A.; et al. Evaluation of Attention-Deficit Hyperactivity Disorder Risk Factors. Int. J. Pediatr. 2013, 2013, 1-6. [CrossRef]

160. Newburg, D.S.; Walker, W.A. Protection of the neonate by the innate immune system of developing gut and of human milk. Pediatr. Res. 2007, 61, 2-8. [CrossRef]

161. Cacho, N.T.; Lawrence, R.M. Innate Immunity and Breast Milk. Front. Immunol. 2017, 8, 584. [CrossRef]

162. Richardson, A.; Puri, B. The potential role of fatty acids in attention-deficit/hyperactivity disorder. Prostaglandins Leukot. Essent. Fat. Acids 2000, 63, 79-87. [CrossRef] [PubMed]

163. Richardson, A.J. Omega-3 fatty acids in ADHD and related neurodevelopmental disorders. Int. Rev. Psychiatry 2006, 18, 155-172. [CrossRef] [PubMed]

164. Bezirtzoglou, E.; Tsiotsias, A.; Welling, G.W. Microbiota profile in feces of breast- and formula-fed newborns by using fluorescence in situ hybridization (FISH). Anaerobe 2011, 17, 478-482. [CrossRef] [PubMed]

165. Fallani, M.; Young, D.; Scott, J.; Norin, E.; Amarri, S.; Adam, R.; Aguilera, M.; Khanna, S.; Gil, A.; Edwards, C.A.; et al. Intestinal Microbiota of 6-week-old Infants Across Europe: Geographic Influence Beyond Delivery Mode, Breast-feeding, and Antibiotics. J. Pediatr. Gastroenterol. Nutr. 2010, 51, 77-84. [CrossRef]

166. Guaraldi, F.; Salvatori, G. Effect of Breast and Formula Feeding on Gut Microbiota Shaping in Newborns. Front. Microbiol. 2012, 2, 94. [CrossRef]

167. Underwood, M.A.; Kalanetra, K.M.; Bokulich, N.A.; Lewis, Z.T.; Mirmiran, M.; Tancredi, D.J.; Mills, D.A. A comparison of two probiotic strains of bifidobacteria in premature infants. J. Pediatr. 2013, 163, 1585-1591.e9. [CrossRef]

168. Underwood, M.A.; German, J.B.; Lebrilla, C.B.; Mills, D.A. Bifidobacterium longum subspecies infantis: Champion colonizer of the infant gut. Pediatr. Res. 2015, 77, 229-235. [CrossRef]

169. Adesman, A.; Soled, D.; Rosen, L. Formula Feeding as a Risk Factor for Attention-Deficit/Hyperactivity Disorder: Is Bisphenol A Exposure a Smoking Gun? J. Dev. Behav. Pediatr. 2017, 38, 545-551.e9. [CrossRef]

170. Mariadason, J.M.; Corner, G.A.; Augenlicht, L.H. Genetic reprogramming in pathways of colonic cell maturation induced by short chain fatty acids: Comparison with trichostatin A, sulindac, and curcumin and implications for chemoprevention of colon cancer. Cancer Res. 2000, 60, 4561-4572.

171. Canani, R.B.; Di Costanzo, M.; Leone, L.; Pedata, M.; Meli, R.; Calignano, A. Potential beneficial effects of butyrate in intestinal and extraintestinal diseases. World J. Gastroenterol. 2011, 17, 1519-1528. [CrossRef]

172. Macfabe, D.F. Enteric short-chain fatty acids: Microbial messengers of metabolism, mitochondria, and mind: Implications in autism spectrum disorders. Microb. Ecol. Heal. Dis. 2015, 26, 28177. [CrossRef] [PubMed]

173. Bercik, P.; Denou, E.; Collins, J.; Jackson, W.; Lu, J.; Jury, J.; Deng, Y.; Blennerhassett, P.; Macri, J.; McCoy, K.D.; et al. The Intestinal Microbiota Affect Central Levels of Brain-Derived Neurotropic Factor and Behavior in Mice. Gastroenterology 2011, 141, 599-609.e3. [CrossRef] [PubMed]

174. Corominas-Roso, M.; Ramos-Quiroga, J.A.; Ribases, M.; Sanchez-Mora, C.; Palomar, G.; Valero, S.; Bosch, R.; Casas, M. Decreased serum levels of brain-derived neurotrophic factor in adults with attention-deficit hyperactivity disorder. Int. J. Neuropsychopharmacol. 2013, 16, 1267-1275. [CrossRef] [PubMed]

175. Akay, A.P.; Resmi, H.; Güney, S.A.; Erkuran, H.; Özyurt, G.; Sargin, E.; Topuzoglu, A.; Tufan, A.E. Serum brain-derived neurotrophic factor levels in treatment-naïve boys with attention-deficit/hyperactivity disorder treated with methylphenidate: An 8-week, observational pretest-posttest study. Eur. Child Adolesc. Psychiatry 2018, 27, 127-135. [CrossRef]

176. Amiri, A.; Torabi Parizi, G.; Kousha, M.; Saadat, F.; Modabbernia, M.J.; Najafi, K.; Atrkar Roushan, Z. Changes in plasma Brain-derived neurotrophic factor (BDNF) levels induced by methylphenidate in children with Attention deficit-hyperactivity disorder (ADHD). Prog. Neuropsychopharmacol. Biol. Psychiatry 2013, 47, 20-24. [CrossRef]

177. Shim, S.H.; Hwangbo, Y.; Kwon, Y.J.; Jeong, H.Y.; Lee, B.H.; Lee, H.J.; Kim, Y.K. Increased levels of plasma brain-derived neurotrophic factor (BDNF) in children with attention deficit-hyperactivity disorder (ADHD). Prog. Neuropsychopharmacol. Biol. Psychiatry 2008, 32, 1824-1828. [CrossRef] 
178. Fujimura, H.; Chen, R.; Nakamura, T.; Nakahashi, T.; Kambayashi, J.-I.; Sun, B.; Altar, C.A.; Tandon, N.N. Brain-derived neurotrophic factor is stored in human platelets and released by agonist stimulation. Thromb. Haemost. 2002, 87, 728-734. [CrossRef]

179. Amjad Khan, W.; Chun-Mei, H.; Khan, N.; Iqbal, A.; Lyu, S.W.; Shah, F. Bioengineered Plants Can Be a Useful Source of Omega-3 Fatty Acids. Biomed. Res. Int. 2017, 2017, 7348919. [CrossRef]

180. Cryan, J.F.; O'Mahony, S.M. The microbiome-gut-brain axis: From bowel to behavior. Neurogastroenterol. Motil. 2011, 23, 187-192. [CrossRef]

181. Weiser, M.J.; Butt, C.M.; Mohajeri, M.H. Docosahexaenoic Acid and Cognition throughout the Lifespan. Nutrients 2016, 8, 99. [CrossRef]

182. Robertson, R.C.; Oriach, C.S.; Murphy, K.; Moloney, G.M.; Cryan, J.F.; Dinan, T.G.; Ross, R.P.; Stanton, C. Omega-3 polyunsaturated fatty acids critically regulate behaviour and gut microbiota development in adolescence and adulthood. Brain Behav. Immun. 2017, 59, 21-37. [CrossRef] [PubMed]

183. Choi-Lundberg, D.L.; Lin, Q.; Chang, Y.-N.; Chiang, Y.L.; Hay, C.M.; Mohajeri, H.; Davidson, B.L.; Bohn, M.C. Dopaminergic Neurons Protected from Degeneration by GDNF Gene Therapy. Science 1997, 275, 838-841. [CrossRef] [PubMed]

184. Bohn, M.C.; Connor, B.; Kozlowski, D.A.; Mohajeri, M.H. Gene transfer for neuroprotection in animal models of Parkinson's disease and amyotrophic lateral sclerosis. Novartis Found Symp. 2000, 231, 70-93. [PubMed]

185. Rao, J.S.; Ertley, R.N.; Lee, H.J.; DeMar, J.C.; Arnold, J.T.; Rapoport, S.I.; Bazinet, R.P. N-3 polyunsaturated fatty acid deprivation in rats decreases frontal cortex BDNF via a p38 MAPK-dependent mechanism. Mol. Psychiatry 2007, 12, 36-46. [CrossRef]

186. Soares, J.C.; Kochunov, P.; Monkul, E.S.; Nicoletti, M.A.; Brambilla, P.; Sassi, R.B.; Mallinger, A.G.; Frank, E.; Kupfer, D.J.; Lancaster, J.; et al. Structural brain changes in bipolar disorder using deformation field morphometry. NeuroReport 2005, 16, 541-544. [CrossRef]

187. Costantini, L.; Molinari, R.; Farinon, B.; Merendino, N. Impact of Omega-3 Fatty Acids on the Gut Microbiota. Int. J. Mol. Sci. 2017, 18, 2645. [CrossRef]

188. Yan, Y.; Jiang, W.; Spinetti, T.; Tardivel, A.; Castillo, R.; Bourquin, C.; Guarda, G.; Tian, Z.; Tschopp, J.; Zhou, R. Omega-3 Fatty Acids Prevent Inflammation and Metabolic Disorder through Inhibition of NLRP3 Inflammasome Activation. Immunity 2013, 38, 1154-1163. [CrossRef]

189. Kaliannan, K.; Li, X.-Y.; Wang, B.; Pan, Q.; Chen, C.-Y.; Hao, L.; Xie, S.; Kang, J.X. Multi-omic analysis in transgenic mice implicates omega-6/omega-3 fatty acid imbalance as a risk factor for chronic disease. Commun. Boil. 2019, 2, 276. [CrossRef]

190. Kaliannan, K.; Wang, B.; Li, X.Y.; Kim, K.J.; Kang, J.X. A host-microbiome interaction mediates the opposing effects of omega-6 and omega-3 fatty acids on metabolic endotoxemia. Sci. Rep. 2015, 5, 11276. [CrossRef]

191. Crippa, A.; Agostoni, C.; Mauri, M.; Molteni, M.; Nobile, M. Polyunsaturated Fatty Acids Are Associated With Behavior But Not With Cognition in Children With and Without ADHD: An Italian study. J. Atten. Disord. 2018, 22, 971-983. [CrossRef]

192. Chang, J.P.; Su, K.P.; Mondelli, V.; Pariante, C.M. Omega-3 Polyunsaturated Fatty Acids in Youths with Attention Deficit Hyperactivity Disorder: A Systematic Review and Meta-Analysis of Clinical Trials and Biological Studies. Neuropsychopharmacology 2018, 43, 534-545. [CrossRef] [PubMed]

193. Anand, P.; Sachdeva, A. Effect of Poly Unsaturated Fatty Acids Administration on Children with Attention Deficit Hyperactivity Disorder: A Randomized Controlled Trial. J. Clin. Diagn. Res. 2016, 10, OC01-OC05. [CrossRef] [PubMed]

194. Gillies, D.; Sinn, J.K.; Lad, S.S.; Leach, M.J.; Ross, M.J. Polyunsaturated fatty acids (PUFA) for attention deficit hyperactivity disorder (ADHD) in children and adolescents. Cochrane Database Syst. Rev. 2012, 7, CD007986. [CrossRef] [PubMed]

195. Watson, H.; Mitra, S.; Croden, F.C.; Taylor, M.; Wood, H.M.; Perry, S.L.; Spencer, J.A.; Quirke, P.; Toogood, G.J.; Lawton, C.L.; et al. A randomised trial of the effect of omega-3 polyunsaturated fatty acid supplements on the human intestinal microbiota. Gut 2018, 67, 1974-1983. [CrossRef] [PubMed]

196. Ilag, L.L. Are Long-Chain Polyunsaturated Fatty Acids the Link between the Immune System and the Microbiome towards Modulating Cancer? Medicines 2018, 5, 102. [CrossRef] [PubMed]

197. Bennet, R.; Eriksson, M.; Nord, C.E. The fecal microflora of 1-3-month-old infants during treatment with eight oral antibiotics. Infection 2002, 30, 158-160. [CrossRef] [PubMed] 
198. Hussey, S.; Wall, R.; Gruffman, E.; O'Sullivan, L.; Ryan, C.A.; Murphy, B.; Fitzgerald, G.; Stanton, C.; Ross, R.P. Parenteral antibiotics reduce bifidobacteria colonization and diversity in neonates. Int. J. Microbiol. 2011, 2011, 130574. [CrossRef] [PubMed]

199. Slykerman, R.F.; Thompson, J.; Waldie, K.E.; Murphy, R.; Wall, C.; Mitchell, E.A. Antibiotics in the first year of life and subsequent neurocognitive outcomes. Acta Paediatr. 2017, 106, 87-94. [CrossRef]

200. Reid, G.; Hammond, J.A. Probiotics. Some evidence of their effectiveness. Can. Fam. Physician 2005, 51, 1487-1493.

201. Hill, C.; Guarner, F.; Reid, G.; Gibson, G.R.; Merenstein, D.J.; Pot, B.; Morelli, L.; Canani, R.B.; Flint, H.J.; Salminen, S.; et al. Expert consensus document. The International Scientific Association for Probiotics and Prebiotics consensus statement on the scope and appropriate use of the term probiotic. Nat. Rev. Gastroenterol. Hepatol. 2014, 11, 506-514. [CrossRef]

202. Kumar, M.; Nagpal, R.; Verma, V.; Kumar, A.; Kaur, N.; Hemalatha, R.; Gautam, S.K.; Singh, B. Probiotic metabolites as epigenetic targets in the prevention of colon cancer. Nutr. Rev. 2013, 71, 23-34. [CrossRef] [PubMed]

203. Reid, G.; Younes, J.A.; Van der Mei, H.C.; Gloor, G.B.; Knight, R.; Busscher, H.J. Microbiota restoration: Natural and supplemented recovery of human microbial communities. Nat. Rev. Microbiol. 2011, 9, 27-38. [CrossRef] [PubMed]

204. Rezac, S.; Kok, C.R.; Heermann, M.; Hutkins, R. Fermented Foods as a Dietary Source of Live Organisms. Front. Microbiol. 2018, 9, 1785. [CrossRef]

205. Savignac, H.M.; Kiely, B.; Dinan, T.G.; Cryan, J.F. Bifidobacteria exert strain-specific effects on stress-related behavior and physiology in BALB/c mice. Neurogastroenterol. Motil. 2014, 26, 1615-1627. [CrossRef] [PubMed]

206. Felice, V.D.; O'Mahony, S.M. The microbiome and disorders of the central nervous system. Pharmacol. Biochem. Behav. 2017, 160, 1-13. [CrossRef] [PubMed]

207. Tsai, S.J. Attention-deficit hyperactivity disorder may be associated with decreased central brain-derived neurotrophic factor activity: Clinical and therapeutic implications. Med. Hypotheses 2007, 68, 896-899. [CrossRef] [PubMed]

208. Pelsser, L.M.; Frankena, K.; Toorman, J.; Rodrigues Pereira, R. Diet and ADHD, Reviewing the Evidence: A Systematic Review of Meta-Analyses of Double-Blind Placebo-Controlled Trials Evaluating the Efficacy of Diet Interventions on the Behavior of Children with ADHD. PLoS ONE 2017, 12, e0169277. [CrossRef] [PubMed] 